\title{
Sulforaphane Potentially Ameliorates Arsenic Induced Hepatotoxicity in Albino Wistar Rats: Implication of PI3K/Akt/Nrf2 Signaling Pathway
}

\author{
Shanmugam Thangapandiyan ${ }^{\mathrm{a}} \quad$ Mathan Ramesh $^{\mathrm{a}}$ Tamilselvan Hema ${ }^{\mathrm{a}}$ \\ Selvaraj Miltonprabu ${ }^{b}$ Md Sahab Uddin ${ }^{c}$ Venkatesan Nandhini ${ }^{a}$ \\ Gunasekaran Bavithra Jothia \\ a'Department of Zoology, Bharathiar University, Coimbatore, Tamilnadu, India, bDepartment of Zoology, \\ University of Madras, Guindy campus, Chennai, Tamilnadu, India, 'Department of Pharmacy, Southeast \\ University, Dhaka, Bangladesh
}

\section{Key Words}

Sulforaphane $\cdot$ Arsenic $・$ Hepatotoxicity $・$ Liver $・$ Nrf2 $•$ PI3K/Akt pathway

\begin{abstract}
Background/Aims: Agriculture and industrial expansion in recent years have resulted in the undue discharge of arsenic into the environment, building arsenic toxicity a major worldwide anxiety. Oxidative stress is considered as the most conspicuous effect of arsenic toxicity. The current study was designed to evaluate the protective ability of sulforaphane (SFN) against arsenic (As) induced hepatotoxicity by activation of PI3K induced Akt and Nrf2 mediated signaling pathway. Methods: For this purpose, male Wistar rats were randomly distributed into 6 groups of 8 rats each: control, Arsenic (5mg/kg BW), SFN plus Arsenic (20, 40, $80 \mathrm{mg} /$ $\mathrm{kg} \mathrm{BW} ; 5 \mathrm{mg} / \mathrm{kg} \mathrm{BW}$ ) and Vit. C plus Arsenic (100mg/kg BW; $5 \mathrm{mg} / \mathrm{kg} \mathrm{BW).} \mathrm{In} \mathrm{this} \mathrm{study,} \mathrm{we}$ have used spectrophotometry for enzymatic antioxidant assays, western blotting and PCR for protein and gene expression. Microtome for histological study. Results: The arsenicinduced oxidative damage was confirmed by a significant $(p<0.05)$ increase in the levels of $A L A D, A s$ concentration and depletion in the antioxidant content. Furthermore, Arsenics treatments significantly $(p<0.05)$ increased the pro-apoptotic marker (Bax) and DNA damage, with decreased Nrf2 protein responsible for liver protection. However, pretreatment with SFN significantly $(p<0.05)$ decreased the levels of ALAD, Arsenic concentration, and brought antioxidant enzymes into normal levels. This was accomplished by inhibition of apoptotic markers via activation of PI3K, Akt and Nrf2 mediated signaling pathway as evident from western blotting and PCR techniques. Conclusion: Moreover, SFN pretreatment shield the liver histoarchitecture observed in Arsenic treated groups suggesting prevention of liver toxicity via
\end{abstract}


PI3K/Akt mediated Nrf2 signaling pathways and could possibly provide a protection against Arsenic induced hepatic burden.

(c) 2019 The Author(s). Published by Cell Physiol Biochem Press GmbH\&Co. KG

\section{Introduction}

Arsenic (As) and a large number of its mixes are powerful toxins in the earth existing in natural and inorganic structures. They are broadly circulated in the earth and their introduction happens fundamentally through tainted water, food and soil [1, 2]. Today, arsenic contamination has turned into an overall concern. In nations like Bangladesh, Taiwan, India, China, Argentina and the USA, arsenic fixations in water have been found to be well over the most extreme satisfactory point of confinement as recommended by WHO rules [3]. Food is the main supply of intake of arsenic in areas where there are no natural or anthropogenic problems of arsenic contamination [4]. Arsenic is immediately ingested from the gastrointestinal tract and aviation route into the circulatory system and is subsequently dispersed to a several organs and causing hepatotoxicity, nephrotoxicity, neurotoxicity, disease, diabetes, atherosclerosis and cardiovascular brokenness [5].

The liver is a complex organ comprising of very much characterized parts that work in an exceedingly coordinated manner. Various medications, synthetic chemicals and heavy metals have appeared to adjust its structure and capacity. Presently, a notable system of arsenic-initiated toxicity is the oxidative stress induction [6]. Inorganic trivalent arsenic (iAs (III)) is dangerous, which increases reactive oxygen species (ROS) via binding with vicinal thiols or biological ligands containing sulfur groups [7]. Recent studies propose that Arsenic applies its harmful impacts through an assortment of systems in which the most observable one is the overabundance of reactive oxygen species (ROS) $[8,9]$. Lin et al., [10] reported that the oxidative stress may create obtained resilience to apoptosis, upgraded cell proliferation, adjusted DNA methylation, genomic instability, and abnormal estrogen signaling involved in the hepatotoxicity by Arsenic [11].

Chelating specialists like British anti-lewisite (BAL) and Dimercaprol sulphonate (DMPS) have for quite some time been used as antidotes for the administration of arsenic toxicity. However, these agents indicated symptoms and inconveniences, for example, non-specificity, inconvenient administration, low therapeutic index and damage liver and kidney [12]. Plant-inferred phytoconstituents have demonstrated to display amazing cancer prevention agent properties and kill the Arsenic-incited ROS generation when contrasted with synthetic antidotes [13]. Sulforaphane (SFN), a phytochemical present in cruciferous vegetables, is nontoxic (isothiocyanates) compound recognized for its anticancer, antidiabetic, antimicrobial, and chemopreventive action in various animal models of diseases $[14,15]$. Several studies have been practiced, in the previous two decades, on the wellbeing impact of SFN rich eating diet on different systems, both in vitro and in vivo $[16,17]$. The real mechanism of chemoprevention activity of SFN is considered as the activation of Nrf2, by means of change of cysteine of Keap 1 [18]. Upgraded Nrf2 signaling and cytoprotective gene action incited by SFN were seen in hepatic cells, both in vivo and in vitro $[16,17]$. Significantly, SFN has not been tried for its capacity to give protection from Arsenic toxicity or to other oxidative and electrophilic stress on the liver in vivo.

In earlier examinations, SFN has demonstrated the mitochondrial liver protection against cisplatin-actuated toxicity in rodents [19] and recently, Jung et al., [17] have announced that SFN enhances acetaminophen-initiated oxidative hepatic damage by abrogation of free radicals and oxidative stress in rats. Nevertheless, to the best of our insight, there is no data concerning the role of SFN in the enhancement of As-prompted oxidative pressure intervened hepatic dysfunction in albino Wistar rats. In this way, the present investigation was attempted to exhibit the recovery of hepatic dysfunction and apoptosis in rats to check whether SFN would, to some extent, improves the arsenic toxicity by means of activation of PI3K initiated Akt and Nrf2 signaling pathways. 


\section{Cellular Physiology Cell Physiol Biochem 2019;52:1203-1222 \begin{tabular}{l|l}
\hline DOl: 10.33594/000000082 & (c) 2019 The Author(s). Published by
\end{tabular} and BiOChemistry Published online: 19 April $2019 \quad$ Cell Physiol Biochem Press GmbH\&Co. KG

\section{Materials and Methods}

\section{Chemicals}

Sodium Arsenite $\left(\mathrm{NaAsO}_{2}\right.$ - 98.5\%purity; Batch number № 605668; Permission no. S72625) 1, 1, 3, 3-tetramethoxy propane, bovine serum albumin and were purchased from Nice Chemical Pvt. Ltd, Mumbai. Sulforaphane ( $\geq 90 \%$ of HPLC purity; Batch number № 2286032; Permission no. SWR048) was procured from Sigma Chemicals, Bangalore. All other biochemicals, chemicals and solvents were of certified analytical grade and purchased from Nice chemicals Mumbai or Himedia Laboratories Pvt. Ltd., Mumbai, India. Reagent kits were obtained from span Diagnostics, Mumbai, India. Antibodies against Bax, Bcl-2, PI3, Akt and $ß$-actin were obtained from Santa Cruz Biotechnology (Santa Cruz, CA).

\section{Animals and diet}

Male albino Wistar rats weighing between 120-160 g each were used for this experiment. They were procured from Kerala Veterinary University, Mannuthy, Kerala, India. The rats were maintained in a controlled environment under standard conditions of temperature $\left(28 \pm 2{ }^{\circ} \mathrm{C}\right)$ and humidity with an alternating light and dark cycle. The animals were fed with commercially available pelleted rat chow (Champaka feed private limited, Bangalore, India) and water ad libitum. After a week of acclimatization, rats were divided into control and test groups. Six group of 8 rats were used in all the groups.

\section{Ethics declaration}

All animals (rats) received humane care, according to the criteria outlined in the Guide for the care and use of Laboratory Animals. Animal handling and experimental procedures were approved by the Institutional Animal Ethics Committee (Registration Number: BU/IAEC/2017/03), Bharathiar University, Coimbatore, India.

\section{Drug treatment}

In the present investigation, $\mathrm{NaAsO}_{2}$ was administered intragastrically at a dose of $5 \mathrm{mg} / \mathrm{kg}$ body weight/day for 4 weeks, which was $1 / 8^{\text {th }}$ of the oral $\mathrm{LD}_{50}$ values in rats [20]. SFN powder was dissolved in distilled water and given orally, 90 min prior to the administration of As, at a dose of 20,40, or $80 \mathrm{mg} /$ $\mathrm{kg}$ BW (body weight) daily for 4 weeks. Vit.C was dissolved in water and given orally 90 min prior to the administration of As, at a dose of $100 \mathrm{mg} / \mathrm{kg}$ BW daily for 4 weeks.

\section{Experimental design}

In the experiment, a total of 48 rats has been used. The rats will be divided into six groups of 8 rats in each group. The groups are as follows: Group 1: normal rats (control); Group 2: As treated (5 mg/kg BW); Group 3: SFN (20 mg/kg BW) + As (5 mg/kg BW); Group 4: SFN (40 mg/kg BW) + As (5 mg/kg BW); Group 5: SFN (80 mg/kg BW) + As (5 mg/kg BW); Group 6: SFN (80 mg/kg BW) + Vit.C (100mg/kg BW). A pilot study was conducted with 3 different doses of SFN $(20,40$, and $80 \mathrm{mg} / \mathrm{kg} \mathrm{BW})$ to identify the effective dose of SFN against As toxicity. It was observed that SFN pretreatment with $80 \mathrm{mg} / \mathrm{kg}$ BW significantly $(P<0.05)$ lowered the elevated levels of aspartate aminotransferase (AST), alanine aminotransferase (ALT), lactate dehydrogenase (LDH), and $\gamma$-glutamyl transferase (GGT) in the serum of As-intoxicated rats when compared with other two doses 20 and 40mg/kg BW of SFN. Hence, we have fixed $80 \mathrm{mg} / \mathrm{kg}$ BW as an effective dose for the rest of the biochemical and molecular studies. After the discovery of effective dose, the groups (6) were reduced in 4 and each contained 8 rats. There are as follows: Group 1: Control; Group 2: As; Group 3: SFN+As; Group 4: SFN alone. The total duration of the study was 28 days (4 weeks). Twenty-four hours (24h) after the administration of the last dose, the rats were sacrificed under mild chloroform. The liver tissue was dissected out, weighed, and washed with a normal saline solution. Liver tissue was minced and homogenized $(10 \%, w / v)$ in $0.025 \mathrm{~mol} \cdot \mathrm{L}-1$ Tris-HCl buffer $(\mathrm{pH} 7.4)$ using a Teflon tissue Homogenizer and centrifuged $\left(3000 \mathrm{~g}\right.$ for $10 \mathrm{~min}$ at $4^{\circ} \mathrm{C}$ ). The resulting clear supernatant was used for various biochemical assays. A small portion of the liver tissue was stored in $10 \%$ formalin for histopathological analysis. 


\section{\begin{tabular}{ll} 
Cellular Physiology & Cell Physiol Biochem 2019;52:1203-1222 \\
\hline DOl: 10.33594/000000082 & 2019 The Author(s). Published by
\end{tabular} \begin{tabular}{ll} 
and Biochemistry POblished online: 19 April 2019 & $\begin{array}{l}\text { O } 2019 \text { The Author(s). Published by } \\
\text { Cell Physiol Biochem Press GmbH\&Co. KG }\end{array}$ \\
\cline { 1 - 2 }
\end{tabular} \\ Thangapandiyan et al.: Sulforaphane Protects Arsenic Induced Hepatotoxicity}

\section{Estimation of liver toxicity in serum markers}

The activities of serum AST (EC. 2.6.1.1), ALT (EC. 2.6.1.2), ALP (EC. 3.1.3.1), and LDH (EC. 1.1.1.27), were assayed using commercially available diagnostic kits (Sigma Diagnostics (I) Private, Ltd., Baroda, India). GGT (EC. 2.3.2.2) activity was determined following the method of Rosalki et al [21]. using $\gamma$-glutamyl- $p$ nitroanilide as the substrate.

Determination of $\delta$-aminolevulinic acid dehydratase (ALAD) in blood and liver tissue

The activity from $\delta$-aminolevulinic acid dehydratase (ALAD) was assayed according to the slightly modified procedure of Berlin and Schaller [22]. The total volume of $0.2 \mathrm{~mL}$ of heparinized blood and $100 \mathrm{mg}$ of liver homogenized was mixed separately with $1.3 \mathrm{~mL}$ of distilled incubated for $10 \mathrm{~min}$ at $37^{\circ} \mathrm{C}$ for complete hemolysis. After adding $1 \mathrm{~mL}$ of standard ALA, the tubes were incubated for $60 \mathrm{~min}$ at $37^{\circ} \mathrm{C}$. The reaction was stopped after $1 \mathrm{~h}$ by adding $1 \mathrm{~mL}$ of trichloroacetic acid (TCA). After centrifugation, an equal volume of Ehrlich reagent $(0.59 \mathrm{~g}$ of dimethylamino benzaldehyde in $12.5 \mathrm{~mL}$ glacial acetic acid $+6 \mathrm{~mL}$ perchloric acid $+1 \mathrm{~mL} 2.5 \%$ mercuric chloride) was added and the absorbance was recorded at $555 \mathrm{~nm}$ after $5 \mathrm{~min}$. The values are expressed as $\mathrm{nmol} / \mathrm{min} / \mathrm{mL}$.

\section{Estimation of arsenic concentration in liver tissue}

A liver sample of $1 \mathrm{~g}$ was used for the detection of arsenic concentration. Liver tissues obtained from the experimental rats were digested by thermal acid microwave digestion using Milestone Microwave Laboratory System (Sorisole (BG) Italy). The samples were heated at $150{ }^{\circ} \mathrm{C}$ for $25 \mathrm{~min}$ and at the pressure of $14 \mathrm{~Pa}$. After cooling to ambient temperature for $15 \mathrm{~min}$, the samples are diluted with $10 \mathrm{ml}$ double distilled water. These samples were used for the analysis. Total arsenic deposition in liver tissue was analyzed by standard inductively coupled plasma-optical emission spectroscopy (Optima 2000 DV ICP-OES, Perkin Elmer, Inc., Waltham, Massachusetts, USA).

\section{Estimation of lipid peroxidation markers}

Lipid peroxidation in the liver was estimated calorimetrically by measuring thiobarbituric acid reactive substances (TBARS) and lipid hydroperoxides (LOOH) as described by Niehiaus and Samuelsson [23] and Jiang et al [24]., respectively. As a hallmark of protein oxidation, total protein carbonyl (PC) content was determined in the liver by the spectrophotometric method described by Levine et al [25]. and expressed in nanomoles of carbonyl per milligram of protein.

\section{Estimation of Enzymatic antioxidants}

Superoxide dismutase (SOD) activity was determined following the method of Kakkar et al [26]., in which the inhibition of formation of NADPH-phenazine methosulphate nitroblue tetrazolium formazon was measured spectrophotometrically at $560 \mathrm{~nm}$. Catalase (CAT) activity was assayed calorimetrically as described by Sinha [27] using dichromate acetic acid reagent. Glutathione peroxidase (GPX) activity was assayed following the method of Rotruck et al [28]. based on the reaction between glutathione remaining after the action of GPX and 5, 5'-dithiobis(2- nitrobenzoic acid) to form a complex that absorbs maximally at $412 \mathrm{~nm}$. Glutathione S-transferase (GST) activity was determined spectrophotometrically, following the method of Habig et al [29]. using dichloro-2, 4-dinitrobenzene as the substrate. Glutathione reductase (GR), which uses NADPH to convert metabolized glutathione (GSSG) to the reduced form, was assayed by the method of Horn and Burns [30].

\section{Estimation of nonenzymatic antioxidants}

GSH content in the liver homogenate was determined by the method of Moron et al [31]. based on the reaction with Ellman's reagent (19.8 mg dithionitrobis benzoic acid in $100 \mathrm{~mL}$ of $0.1 \%$ sodium citrate). Total sulfhydryl groups (TSH) were measured after reaction with dithionitrobis benzoic acid, using the method of Ellman [32]. Concentrations of vitamins C and E were measured following the methods of Omaye et al [33]. and Desai [34], respectively. 


\section{Cellular Physiology Cell Physiol Biochem 2019;52:1203-1222 \\ \begin{tabular}{l|l}
\hline DOI: 10.33594/000000082 & (c) 2019 The Author(s). Published by
\end{tabular} \\ and BiOChemistry Published online: 19 April $2019 \quad$ Cell Physiol Biochem Press GmbH\&Co. KG \\ Thangapandiyan et al.: Sulforaphane Protects Arsenic Induced Hepatotoxicity}

\section{Immunohistochemistry}

To examine the protective effects of SFN on markers of inflammation and apoptosis in the liver, Bax and Bcl-2 expression in the liver were assessed by Immunohistochemical staining. Liver sections on polylysinecoated slides obtained were fixed in neutral-buffered formalin, embedded in paraffin, and were treated for Bax and Bcl-2 antibodies for Immunohistochemical analysis. The procedures were processed according to the manufacturer's protocol recommended for the Bax and Bcl-2 immunohistochemistry with slight modifications.

Following deparaffinization and rehydration, sections were irradiated with $0.1 \mathrm{~mol} \mathrm{l}^{-1}$ sodium citrate buffer ( $\mathrm{pH}$ 6.0) in a microwave oven (medium-low temperature) for $20 \mathrm{~min}$. Then, the sections were exposed to $3 \% \mathrm{H}_{2} \mathrm{O}_{2}$ for $10 \mathrm{~min}$ to bleach endogenous peroxidases, followed by rinsing 3 times in Tris buffer ( $\mathrm{pH}$ 7.4) for $10 \mathrm{~min}$. Sections were selectively incubated under humid conditions using an anti-NFkB antibody (1:100; Biolegend, San Diego, California, USA), anti-Bax antibody (1:200; Santa Cruz Biotechnology Inc., Dallas, Texas, USA) and anti-Bcl-2 antibody (1:200; Thermo Fisher Scientific, Waltham, Massachusetts, USA) for overnight at $4^{\circ} \mathrm{C}$. The next day, slides were washed 3 times in Tris buffer for $10 \mathrm{~min}$ each. The specificity of the antibodies was tested by the omission of the primary antibodies and a positive control of rat tonsil tissue. After washing in Tris buffer ( $\mathrm{pH} 7.4$ ), tissues were visualized with 3, 30-diaminobenzidine and counterstained with hematoxylin. Finally, the sections were dehydrated in xylene, mounted with a mixture of distyrene, a plasticizer and xylene (DPX) and coverslipped. Slides prepared for each case were examined using light microscopy. Positive and negative controls were conducted in parallel with Bax-and Bcl-2 stained sections. Staining of sections with commercially available antibodies served as the positive control. Negative controls included staining tissue sections with the omission of the primary antibody.

\section{Determination DNA fragmentation assay (Comet assay)}

DNA damage was estimated by alkaline single-cell gel electrophoresis (Comet assay) according to the method of Singh et al [35].. In this method, the cells were first lysed to form nucleoids. During electrophoresis, DNA fragments (from damaged DNA) streamed towards anode while the undamaged DNA trapped within the nucleus. When they are stained with SYBR green-I, damaged DNA gave the appearance of a comet tail and undamaged DNA gave the spherical appearance. Prefrosted slides were prepared by pouring 3.0-5.0 $\mathrm{mL}$ of $1 \%$ normal agarose over clean glass slides. It was allowed to dry at room temperature and placed in a hot-air oven at $70^{\circ} \mathrm{C}-80^{\circ} \mathrm{C}$ for $30 \mathrm{~min}$. A freshly prepared suspension of $100 \mu \mathrm{L}$ of hepatocytes with $1 \%$ lowmelting-point agarose (LMPA; 1:3 ratio) was cast on to pre frosted microscopic slides, immediately covered with a coverslip and kept for $10 \mathrm{~min}$ in a refrigerator to solidify. Then the coverslip was removed and a top layer of $100 \mu \mathrm{L}$ of LMPA was added and the slides were again cooled for $10 \mathrm{~min}$. The cells were then lysed by immersing the slides in the lysis solution for $1 \mathrm{~h}$ at $4^{\circ} \mathrm{C}$. After lysis, slides were placed in a horizontal electrophoresis tank. The unit was filled with electrophoresis buffer to a level of $0.25 \mathrm{~cm}$ above the slides. The cells were exposed to the alkaline electrophoresis solution for $20 \mathrm{~min}$ to allow DNA unwinding. Electrophoresis was conducted in a cold condition for $20 \mathrm{~min}$ at $25 \mathrm{~V}$ and $300 \mathrm{~mA}$. After electrophoresis, the slides were placed horizontally and neutralized with Tris-HCl buffer. Finally, $50 \mu \mathrm{L}$ of SYBR green-I $(1: 10,000)$ dilution $)$ was added to each slide and analyzed using a fluorescence microscope. To prevent additional DNA damage, all steps were conducted under dimmed light or in the dark. Twenty-five images were randomly selected from each sample and were examined at 200 magnifications in a fluorescence microscope connected to a personal computer-based image analysis system, Komet v. 5.0 (Kinetics Imaging Ltd., Liverpool, UK). The relative amount of DNA appearing at the tail of the comet (\% tail DNA), tail length and tail moment (\% tail DNA × length) were linearly related to DNA break frequency.

\section{Quantitative real time-PCR analysis}

RNA was isolated from mouse liver tissue using TriZol Reagent (TaKaRa, Japan). After using Prime Script TM RT reagent Kit with gDNA Eraser (TaKaRa, Japan), qPCR of liver tissue was performed using SYBR Green reagent (TaKaRa, Japan) on PCR detection system (ABI 7500, Applied Biosystems, USA). Rat mRNA from hepatocytes was isolated using Tri-reagent (Sigma-Aldrich) and assayed with TaqMan control reagents (ABI PRISM 7700, Applied Biosystems, The Netherlands). The following primer pairs were used for this analysis: SOD1: forward: 5'-TAACTGAAGGCCAGCATGGG- 3'; reverse: 5'-CATGGACCACCATTGTACGG 3'; CAT: forward: 5' CACTCAGGTGCGGACATTCT 3'; reverse: 5' TCCGGAGTGGGAGAATCCAT3'; $\beta$ actin: forward: 5' AGCCTTCC 


\section{Cellular Physiology Cell Physiol Biochem 2019;52:1203-1222 \\ \begin{tabular}{ll|l} 
and Biochemistry & $\begin{array}{l}\text { DOl: 10.33594/000000082 } \\
\text { Published online: } 19 \text { April 2019 }\end{array}$ & $\begin{array}{l}\text { O } 2019 \text { The Author(s). Published by } \\
\text { Cell Physiol Biochem Press GmbH\&Co. KG }\end{array}$ \\
\cline { 2 - 3 } &
\end{tabular} \\ Thangapandiyan et al.: Sulforaphane Protects Arsenic Induced Hepatotoxicity}

TTCTTGGGTATGGAATC 3'; reverse: 5' GGAGCAATGATCTT GATCTTCATGG- ${ }^{\prime}$. These primers were designed using Primer3 and synthesized by Integrated DNA Technologies, Inc. (IDT, Coralville, IA, USA). All real-time PCR assays were performed in triplicate. The relative quantitative analysis was carried out by comparing the threshold cycle number for target genes and a reference $\beta$-actin mRNA.

\section{Western blot analysis}

Liver tissues (100 mg) were homogenized in RIPA lysis buffer (50 mM Tris- $\mathrm{HCl}, \mathrm{pH} 7.4 ; 150 \mathrm{mM}$ $\mathrm{NaCl}, 0.25 \%$ deoxycholic acid,1\%NP-40, and $1 \mathrm{mM}$ EDTA) containing EDTA-free protease inhibitor cocktail (Thermo Scientific, USA). The protein was resolved by SDS-PAGE and transferred to PVDF membranes. Membranes were incubated with blocking buffer (5\% (w/v) skimmed milk powder in $1 \times$ TBS containing $0.1 \%$ Tween-20 for $1 \mathrm{~h}$, then incubated with rabbit polyclonal antibodies for anti-PI3K, anti-Akt anti-Nrf2 and $\beta$-actin overnight at $4{ }^{\circ} \mathrm{C}$ (Santa Cruz Biotechnology, CA, USA). Membranes were washed and incubated for $1 \mathrm{~h}$ at room temperature with HRP-linked secondary antibodies. After washing, membranes were detected by Enhanced Chemiluminescence (ECL) kit and exposed to X-ray films (Kodak, India).

\section{Histopathology and scoring analysis}

For qualitative analysis of liver histology, the tissue samples were fixed for $48 \mathrm{~h}$ in $10 \%$ formalinsaline and dehydrated by passing successfully through different mixtures of ethyl alcohol-water, cleaned with xylene, and embedded in paraffin. Sections of the tissue (5-6 $\mu \mathrm{m}$ thick) were prepared using a rotary microtome, stained with haematoxylin and eosin dye and then mounted in a neutral deparaffinized xylene medium for microscopic examinations. Histopathology scoring was performed to evaluate the severity of liver damage using a semi-quantitative scale. All sections were evaluated for the degree of necrosis, inflammation, vacuolization, inflammatory cell infiltration, and sinusoidal dilation. Each liver slide was examined and assigned scores for severity of changes using the following scale: None $(-=0 \%)$, mild $(+=$ $<25 \%)$, moderate $(++=25-50 \%)$, severe $(+++=50-75 \%)$, and more severe $(++++=>75 \%)$ damage.

\section{Statistical analysis}

The values are expressed as mean \pm SD. The results were evaluated using one-way analysis of variance (ANOVA) followed by Duncan's multiple range test (DMRT), using SPSS 16 software package (SPSS Inc, Chicago, IL). $p$-values less than 0.05 were regarded as statistically significant.

\section{Results}

\section{Effects of SFN on liver serum marker enzymes}

The levels of serum hepatic marker enzymes in the control and experimental rats are shown in Table 1. Oral administration of Arsenic ( $5 \mathrm{mg} / \mathrm{kg} \mathrm{BW}$ ) caused abnormal liver function in rats. The activities of serum hepatic marker enzyme AST, ALT, ALP, LDH, and GGT, were significantly $(p<0.05)$ increased when compared to the control. Pre-oral administration of SFN ( $80 \mathrm{mg} / \mathrm{kg} \mathrm{BW})$ along with As group significantly $(p<0.05)$ decreased the levels of serum hepatic marker enzymes when compared to the Astreated rats. Restoration of hepatic marker enzymes was at a maximum using the dose level $(80 \mathrm{mg} / \mathrm{kg}$ BW) of SFN when compared to the other 2 doses (20 and $40 \mathrm{mg} / \mathrm{kg} \mathrm{BW}$ ). Based on these findings, $80 \mathrm{mg} /$ $\mathrm{kg}$ BW of SFN was fixed as the effective dose and used for further biochemical investigations.

Table 1. Effect of SFN and As on the serum hepatic marker enzymes in control and experimental rats. Note: Values are given as the mean \pm SD for 8 rats in each group. Values not sharing a common or same alphabet letter $\left({ }^{\mathrm{a}-\mathrm{f}}\right)$ and they differ significantly at $\mathrm{P}<0.05$. (Duncan's multiple range test). SFN: Sulforaphane, As: Arsenic

\begin{tabular}{lccccc}
\hline Groups & $\begin{array}{c}\text { AST } \\
(\mathrm{IU} / \mathrm{L})\end{array}$ & $\begin{array}{c}\text { ALT } \\
(\mathrm{IU} / \mathrm{L})\end{array}$ & $\begin{array}{c}\text { ALP } \\
(\mathrm{IU} / \mathrm{L})\end{array}$ & $\begin{array}{c}\text { LDH } \\
(\mathrm{IU} / \mathrm{L})\end{array}$ & $\begin{array}{c}\text { GGT } \\
(\mathrm{IU} / \mathrm{L})\end{array}$ \\
\hline $\begin{array}{l}\text { Control } \\
\text { Arsenic }\end{array}$ & $60.77 \pm 4.42^{\mathrm{a}}$ & $23.93 \pm 0.68^{\mathrm{a}}$ & $72.59 \pm 3.81^{\mathrm{a}}$ & $108.71 \pm 7.79^{\mathrm{a}}$ & $0.68 \pm 0.07^{\mathrm{a}}$ \\
$(5 \mathrm{mg} / \mathrm{kg} / \mathrm{bw})$ & $104.18 \pm 5.15^{\mathrm{b}}$ & $52.53 \pm 5.72^{\mathrm{b}}$ & $118.90 \pm 7.48^{\mathrm{b}}$ & $154.22 \pm 11.23^{\mathrm{b}}$ & $0.99 \pm 0.11^{\mathrm{b}}$ \\
$\mathrm{SFN}+\mathrm{As}$ & & & & & \\
$(20 \mathrm{mg} / \mathrm{kg} / \mathrm{bw})$ & $93.22 \pm 3.28^{\mathrm{c}}$ & $40.36 \pm 1.23^{\mathrm{c}}$ & $101.56 \pm 5.71^{\mathrm{c}}$ & $147.29 \pm 10.59^{\mathrm{c}}$ & $0.91 \pm 0.09^{\mathrm{c}}$ \\
SFN $+\mathrm{As}$ & & & & & \\
$(40 \mathrm{mg} / \mathrm{kg} / \mathrm{bw})$ & $84.37 \pm 1.62^{\mathrm{d}}$ & $35.77 \pm 1.81^{\mathrm{d}}$ & $91.91 \pm 3.81^{\mathrm{d}}$ & $140.43 \pm 10.82^{\mathrm{d}}$ & $0.85 \pm 0.06^{\mathrm{d}}$ \\
$\mathrm{SFN}+\mathrm{As}$ & & & & & \\
$(80 \mathrm{mg} / \mathrm{kg} / \mathrm{bw})$ & $75.48 \pm 2.22^{\mathrm{e}}$ & $27.84 \pm 1.23^{\mathrm{e}}$ & $83.55 \pm 4.36^{\mathrm{e}}$ & $134.83 \pm 8.54^{\mathrm{e}}$ & $0.74 \pm 0.08^{\mathrm{e}}$ \\
Vit.C $+\mathrm{As}$ \\
$(100 \mathrm{mg} / \mathrm{kg} / \mathrm{bw})$ & $88.43 \pm 2.79^{\mathrm{f}}$ & $37.83 \pm 1.09^{\mathrm{f}}$ & $95.49 \pm 3.35^{\mathrm{f}}$ & $137.13 \pm 7.15^{\mathrm{f}}$ & $0.80 \pm 0.06^{\mathrm{f}}$ \\
\hline
\end{tabular}


The treatment of Vit. C (100mg/kg BW) along with As dose $(5 \mathrm{mg} / \mathrm{kg}$ BW) significantly ( $p<$ $0.05)$ reduced the alterations in serum hepatic enzymes when compared to the control and in As - treated rats.

\section{Effect of SFN treatments on As accumulation and ALAD}

Fig. $1 \mathrm{~A}$ shows the level of blood and hepatic ALAD in control and experimental animals. Arsenic intoxicated animals showed a significant $(p$ $<0.05$ ) decrease in the levels of blood and hepatic ALAD when compared to the control. Pre-oral administration with SFN significantly $(p<0.05)$ restored the altered levels of blood and hepatic ALAD when compared to the only As - treated rats. SFN alone did not show any changes when compared to the control. The effect of SFN on the levels of As-accumulation in the control and experimental rats were depicted in Fig. 1B. There was a significant $(p<0.05)$ increase in the levels of As in experimental animals when compared to the control. However, pre-administration of SFN significantly $(p<0.05)$ hold

Fig. 1. (A) Effect of SFN and $\mathrm{Ar}$ on the activities of ALAD in blood and liver of control and experimental rats. (B) Effect of SFN on the accumulation of As in liver tissue of control and experimental rats. Values are expressed as mean \pm SD for groups of eight rats in each. Statistical significance was determined by one way ANOVA (Duncan's Multiple Range Test). Values not sharing a common or same alphabet letter ${ }^{\left({ }^{a-}\right)}$ and they differ significantly at $\mathrm{P}<0.05$ (Duncan's multiple range test).

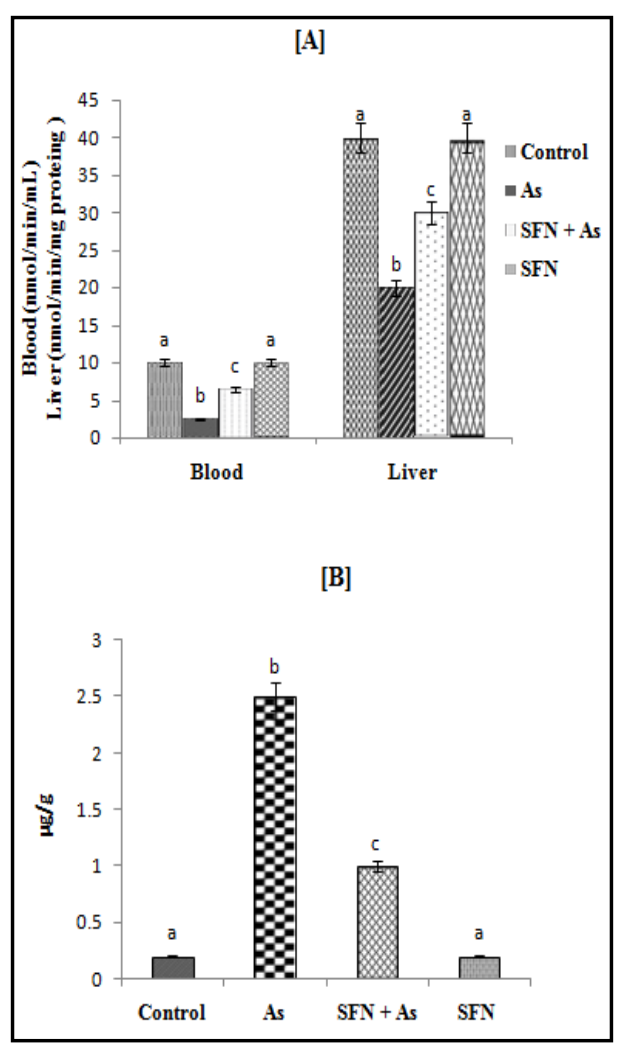

Fig. 2. Effect of SFN and As on TBARS, LOOH and $\mathrm{PC}$ in the liver of control and experimental rats. Values are expressed as mean \pm SD for groups of eight rats in each. Statistical significance was determined by one way ANOVA (Duncan's Multiple Range Test). Values not sharing a common or same alphabet letter ${ }^{\mathrm{a}-\mathrm{f}}$ ) and they differ significantly at $\mathrm{P}<0.05$ (Duncan's multiple range test).

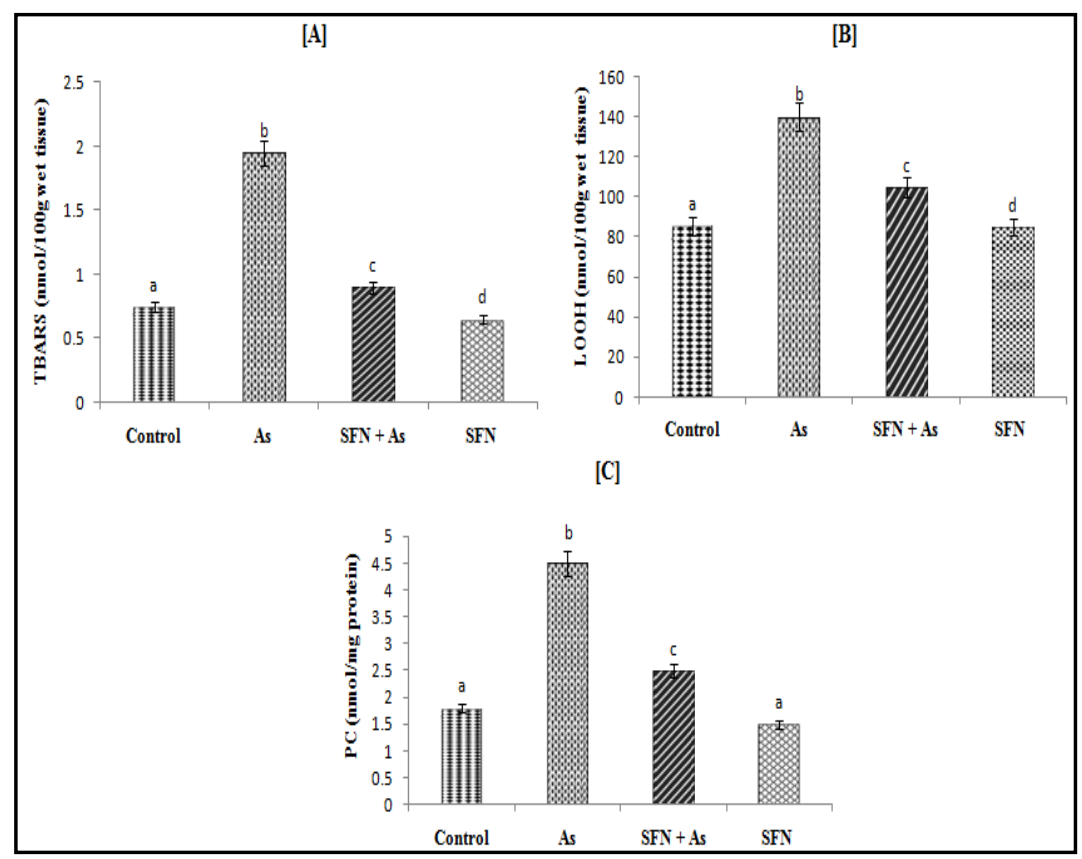


back the As accumulation when compared to As -treated rats. SFN alone treated rats also showed similar results of control.

\section{Effect of SFN on lipid} peroxidation markers

Lipid peroxidation, a process induced by oxidative stress, is the primary indicator of oxidative damage to liver cells. The changes in the levels of hepatic thiobarbituric acid reactive substances, lipid hydroperoxides, and protein carbonyl content in control and experimental rats are shown in Fig. 2. The levels of TBARS (Fig. 2A), LOOH (Fig. 2B), and PCC (Fig. 2C) were significantly increased $(p<0.05)$ in As- treated rats compared to the control groups. However, co-administration of SFN with arsenic significantly $(p<0.05)$ lowered the TBARS, $\mathrm{LOOH}$ and PCC in the liver when compared to only As- treated rats. SFN alone did not exhibit any significant changes as compared to that of control.

\section{Effect of SFN treatment on} enzymatic antioxidants level

Table 2 demonstrates the activities of enzymatic antioxidants namely superoxide dismutase, catalase, glutathione peroxidase, glutathioneS-transferase, and glutathione reductase in the liver of control and experimental rats. A significant $(p<0.05)$ decrease is observed in the activities of enzymatic antioxidants in Astreated rats when compared to the control. Pre-treatment of SFN along with As significantly $(p<0.05)$ increased the levels of enzymatic antioxidants when compared to that of Astreated animals. SFN alone treated rats showed a significant $(p<0.05)$ increased enzymatic antioxidants levels as compared to control.

\section{Effect of SFN treatment on non-enzymatic antioxidants level}

The changes in the levels of hepatic non-enzymatic antioxidants namely reduced glutathione, a total sulfhydryl group, Vitamins $\mathrm{C}$ and $\mathrm{E}$ in the liver of control and experimental rats are shown in Table - 3. A significant $(p<0.05)$ decrease in the levels of hepatic nonenzymatic antioxidants was observed in rats treated with As when compared to the control. Pre-oral administration of SFN ( $80 \mathrm{mg} / \mathrm{kg} \mathrm{BW})$ along with arsenic significantly $(p<0.05)$ renovated the levels of hepatic non-enzymatic antioxidants to near normal. SFN alone treated rat also showed a significant $(p<0.05)$ hiked levels of non-enzymatic antioxidant when compared to control.
Table 2. Effect of SFN and As on the enzymatic antioxidant levels in control and experimental rats. Note: Values are given as the \pm SD for 8 rats in each group. Values not sharing a common (Duncan's multiple range test). SOD, 1 unit of enzyme activity was taken as the enzyme reaction, which gave $50 \%$ inhibition of micromoles of $\mathrm{H}_{2} \mathrm{O}_{2}$ used per minute per milligram of protein; GPX, micromoles of GSH consumed per minute per milligram GSH conjugate formed per minute per milligram of protein; GR, micromoles of NADPH oxidized per minute per milligram of protein; SFN: Sulforaphane, As: Arsenic

\begin{tabular}{lcccc}
\hline Groups & Control & $\begin{array}{c}\text { As } \\
(5 \mathrm{mg} / \mathrm{kg} / \mathrm{bw})\end{array}$ & $\begin{array}{c}\mathrm{SFN}+\mathrm{As} \\
(80 \mathrm{mg} / \mathrm{kg} / \mathrm{bw})+(5 \mathrm{mg} / \mathrm{kg} / \mathrm{bw})\end{array}$ & $\begin{array}{c}\mathrm{SFN} \\
(80 \mathrm{mg} / \mathrm{kg} / \mathrm{bw})\end{array}$ \\
\hline SOD & $10.78 \pm 0.73^{\mathrm{a}}$ & $6.29 \pm 0.34^{\mathrm{b}}$ & $9.12 \pm 0.56^{\mathrm{c}}$ & $12.18 \pm 0.80^{\mathrm{d}}$ \\
CAT & $78.44 \pm 8.59^{\mathrm{a}}$ & $56.40 \pm 4.80^{\mathrm{b}}$ & $67.26 \pm 8.26^{\mathrm{c}}$ & $83.34 \pm 9.55^{\mathrm{d}}$ \\
GPx & $11.20 \pm 0.61^{\mathrm{a}}$ & $7.50 \pm 0.33^{\mathrm{b}}$ & $9.64 \pm 0.69^{\mathrm{c}}$ & $13.39 \pm 0.76^{\mathrm{d}}$ \\
GST & $21.9 \pm 3.6^{\mathrm{a}}$ & $10.9 \pm 3.3^{\mathrm{b}}$ & $18.10 \pm 3.7 \mathrm{c}$ & $24.6 \pm 3.9^{\mathrm{d}}$ \\
GR & $0.36 \pm 0.08^{\mathrm{a}}$ & $0.19 \pm 0.04^{\mathrm{b}}$ & $0.29 \pm 0.06^{\mathrm{c}}$ & $0.40 \pm 0.08^{\mathrm{d}}$ \\
\hline
\end{tabular}

Table 3. Effect of SFN and As on the non enzymatic antioxidant levels in control and experimental rats. Note: Values are given as the mean \pm SD for 8 rats in each group. Values not sharing a common or same letter $\left({ }^{\mathrm{a}-\mathrm{d}}\right)$ and they differ significantly at $\mathrm{P}<0.05$ (Duncan's multiple range test). SFN: Sulforaphane, As: Arsenic

\begin{tabular}{lcccc}
\hline Groups & Control & $\begin{array}{c}\mathrm{As} \\
(5 \mathrm{mg} / \mathrm{kg} / \mathrm{bw})\end{array}$ & $\begin{array}{c}\mathrm{SFN}+\mathrm{As} \\
(80 \mathrm{mg} / \mathrm{kg} / \mathrm{bw})+(5 \mathrm{mg} / \mathrm{kg} / \mathrm{bw})\end{array}$ & $\begin{array}{c}\mathrm{SFN} \\
(80 \mathrm{mg} / \mathrm{kg} / \mathrm{bw})\end{array}$ \\
\hline $\begin{array}{l}\text { GSH } \\
(\mu \mathrm{g} / \mathrm{g} \text { protein })\end{array}$ & $16.30 \pm 3.44^{\mathrm{a}}$ & $10.13 \pm 0.69^{\mathrm{b}}$ & $14.03 \pm 0.84^{\mathrm{c}}$ & $18.39 \pm 3.56^{\mathrm{d}}$ \\
TSH & & & $13.66 \pm 0.23^{\mathrm{c}}$ & $17.74 \pm 0.31^{\mathrm{d}}$ \\
$(\mu \mathrm{g} / \mathrm{g}$ protein $)$ & $16.59 \pm 0.27^{\mathrm{a}}$ & $10.73 \pm 0.14^{\mathrm{b}}$ & & \\
$\begin{array}{l}\text { Vit.C } \\
(\mu \mathrm{mol} / \mathrm{mg} / \text { tissue })\end{array}$ & $0.78 \pm 0.10^{\mathrm{a}}$ & $0.46 \pm 0.06^{\mathrm{b}}$ & $0.71 \pm 0.09 \mathrm{c}$ & $0.85 \pm 0.10^{\mathrm{d}}$ \\
$\begin{array}{l}\text { Vit.E } \\
(\mu \mathrm{mol} / \mathrm{mg} / \text { tissue })\end{array}$ & $7.49 \pm 0.55^{\mathrm{a}}$ & $5.25 \pm 0.29^{\mathrm{b}}$ & $7.36 \pm 0.38^{\mathrm{c}}$ & $7.78 \pm 0.51^{\mathrm{d}}$ \\
\hline
\end{tabular}


Fig. 3. Effect of SFN and As on the immunohistochemistry expression of Bax in control and experimental rats (A) Control rats: hepatocytes are no stained (NS) with the Bax antibody. (B\&C) As treated rats show the strong immunopositivity (SIP) Bax in the liver tissue. (D) As treated rats pretreated with SFN shows markedly reduced immunoreactivity (MRI) in liver tissue. (E) SFN treated rats also showed similar to that of control liver tissue appearance. Magnification $\times 200$.

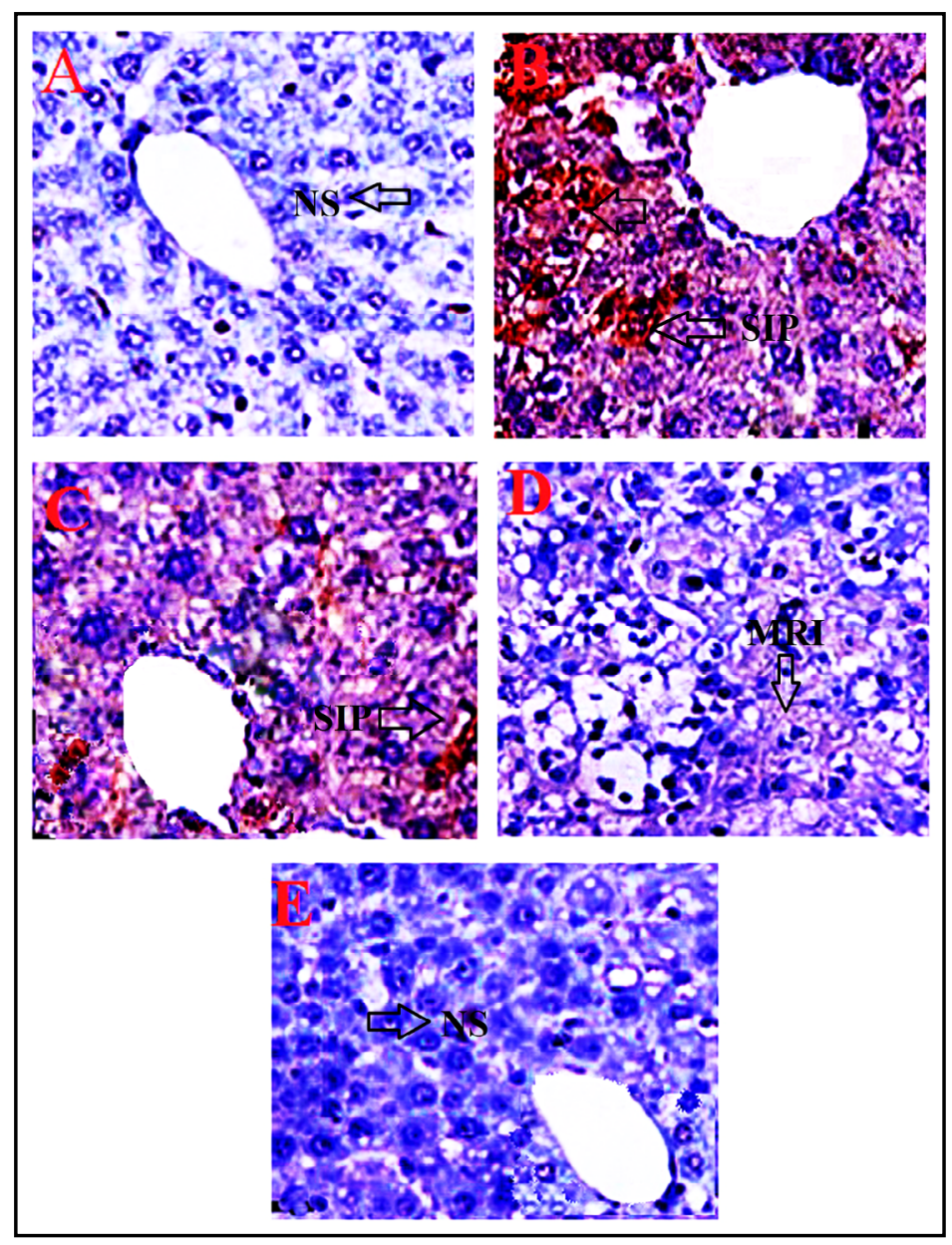

Effect of SFN treatments on immunohistochemistry

The effect of SFN on Arsenic induced expression of immunohistochemistry such as Bax and Bcl-2 proteins are given in Fig. 3 and 4. A significant $(p<0.05)$ expression of Bax was observed in As-treated liver tissue (Fig. 3B and C) when compared to the control (Fig. 3A). However, pre-treatment with SFN caused a significant $(p<0.05)$ reduction (Fig. 3D) in the overexpression of Bax in As- treated rats, when compared to the control and As - treated rats (Fig. 3A\&B). SFN alone (Group IV) treated rats showed significant decreased expression of Bax (Fig. 3E) when compared to control.

The Immunohistochemical study of Bcl-2 (Fig. 4) revealed moderate expression in control (Fig. 4A) animals. There was no significant $(p<0.05)$ Bcl-2 expression observed in As-treated rats (Fig.4B and C) compared to the control groups. On the other hand, pretreatment with SFN to As -treated rats significantly $(p<0.05)$ increased the Bcl-2 expression (Fig. 4D) when compared to As-treated rats. Similarly, SFN alone (Group IV) treated rats showed significant increased expression of Bcl2 (Fig. 4E) when compared to control and As-treated rats.

\section{Effect of SFN treatments on liver DNA damage}

Fig. 5 shows the alterations in the comet assay parameters of control and experimental rats. A significant $(p<0.05)$ increase in different comet assay parameters such as \% DNA in the tail, tail length and tail movement (Fig. 5A and B) were observed in rats treated with As when compared to the control. Pre-treatment of SFN along with As significantly ( $p<$ 0.05 ) reduced the \% DNA in the tail, tail length and tail movement in hepatocytes. SFN alone treated rats showed no or minimal DNA migration as compared to control. 
Fig. 4. Effect of SFN and As on the immunohistochemistry expression of Bcl-2 in control and experimental rats. (A) Control rats: hepatocytes are strongly stained (SS) with the anti-apoptotic Bcl-2 antibody. (B\&C) As treated rats show the decreased immunoreactivity (DIR) of Bcl-2 antibody in the liver tissue. (D) As treated rats pre-treated with SFN shows markedly increased immunoreactivity (MII) of Bcl2 in liver tissue. (E) SFN treated rats also showed similar to that of control liver tissue appearance. Magnification $\times 200$.

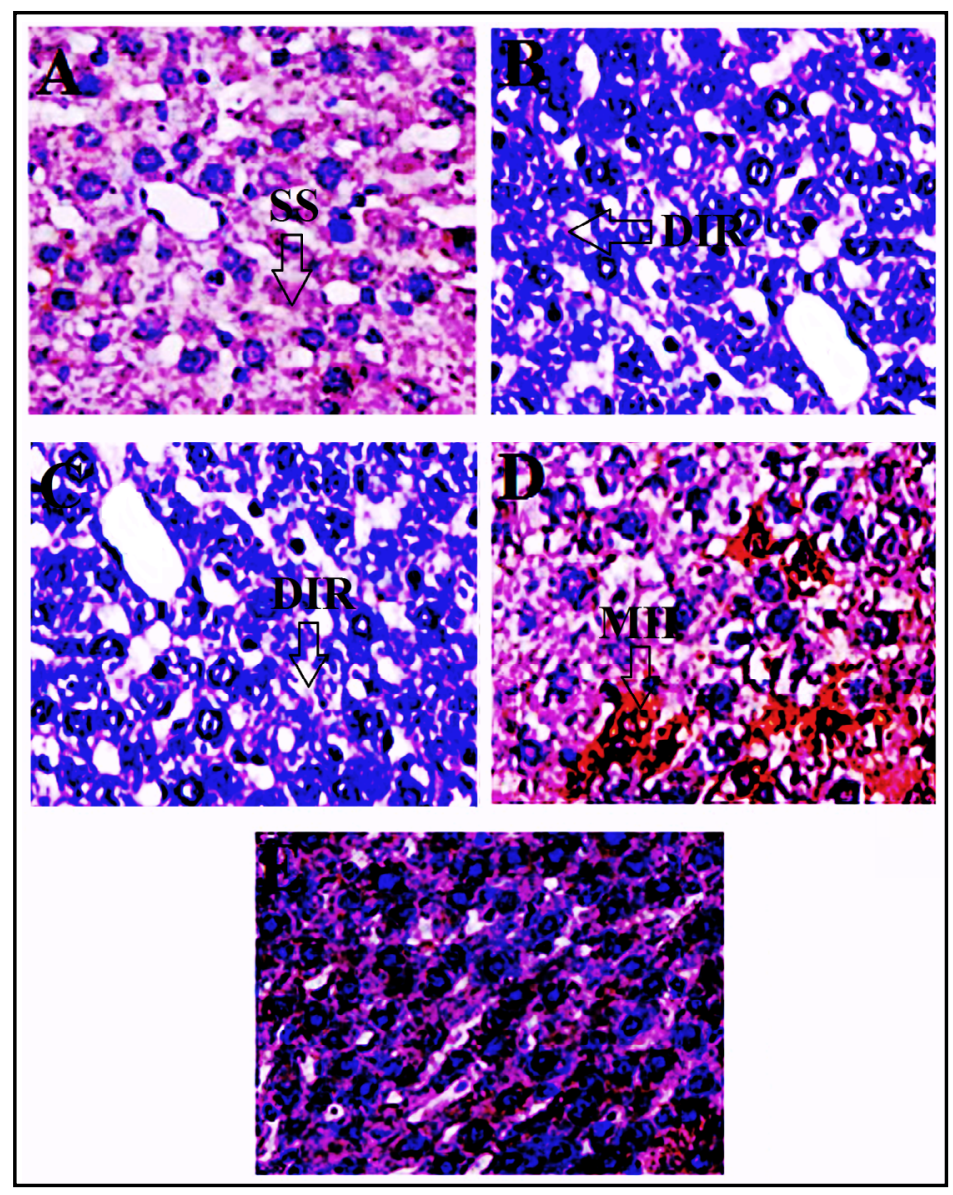

\section{Effect of SFN treatments on RT-PCR}

To further confirm the protective role of SFN on As-treated animals, RT-PCR changes in control and experimental rats were shown in Fig. 6. A significant $(p<0.05)$ decrease in the levels of SOD1 (Fig. 6A) and catalase (CAT) (Fig. 6B) mRNA appearance was observed in As-intoxicated rats when compared to the control. Rats pre-administrated with SFN significantly $(p<0.05)$ increased SOD1 and CAT levels in the liver tissue when compared to the As - treated rats. SFN alone treated rat also showed a significant $(p<0.05)$ increase levels of SOD1 and catalase mRNA appearance as compared to control and SFN+As group.

\section{Effect of SFN treatments on western blotting}

Fig. 7A represents the western blot analysis of Nrf2, PI3 and Akt in liver tissue of control and experimental groups. Densitometric analysis of Nrf2, PI3 and Akt by western blots is given in Fig. 7B. The expression of Nrf2 significantly $(p<0.05)$ down-regulated along with PI3 and Akt in As-intoxicated rats. Pre-administration of SFN resulted in a significant $(p<$ 0.05 ) upregulated expression of Nrf2, PI3 and Akt when compared to As - treated rats. SFN alone treated rats did not showed any significant $(p<0.05)$ expression on Akt, PI3 levels however, Nrf2 significantly $(p<0.05)$ upregulated when compared to control and As + SFN group.

\section{Effect of SFN treatments on histopathology}

The histopathological studies showed that arsenic administration induces severe pathological changes in theliver histoarchitecture (Fig. 8) and further confirmed by histological scoring in control and experimental rats (Table 4). The liver of control rats (Fig. 8A) and SFN (Fig. 8E) treated rats showed a normal histoarchitectural pattern of the liver. However, 
Fig. 5. (A) Representative photomicrographs of comets stained with cyber green showing the DNA migration pattern in control and experimental hepatocytes. (A) Control group shows no DNA migration. (B) Astreated group shows extensive DNA migration. (C) SFN-treated + As-intoxicated group shows minimal DNA migration. D) Sulforaphane (SFN)-treated group shows no DNA migration. (B) Effect of SFN and As on DNA damage (in terms of \% tail DNA, tail length, tail moment,) in the hepatocytes of control and experimental rats. Arbitrary unit $=\%$ tail DNA $\times$ tail length. Values are expressed as mean \pm SD for groups of eight rats in each. Statistical significance was determined by one way ANOVA (Duncan's Multiple Range Test). Values not sharing a common or same alphabet letter $\left(^{a-f}\right)$ and they differ significantly at $\mathrm{P}<0.05$ (Duncan's multiple range test). Magnification $\times 200$.
[A]

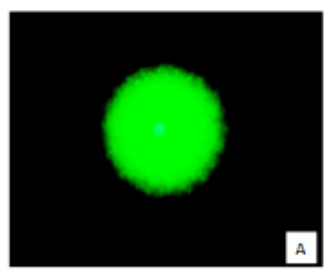

Control

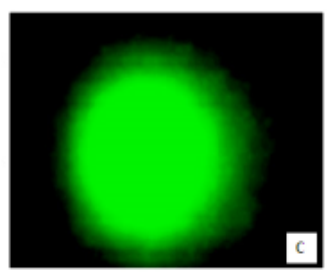

$\mathrm{SFN}+\mathrm{As}$

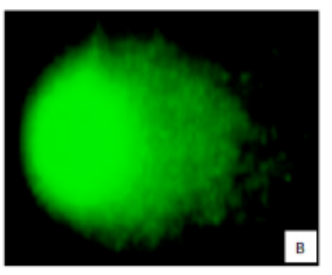

As

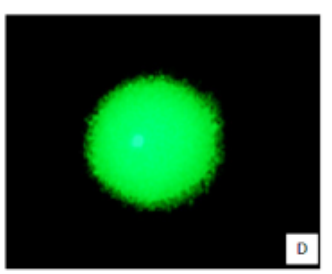

SFN

[B]

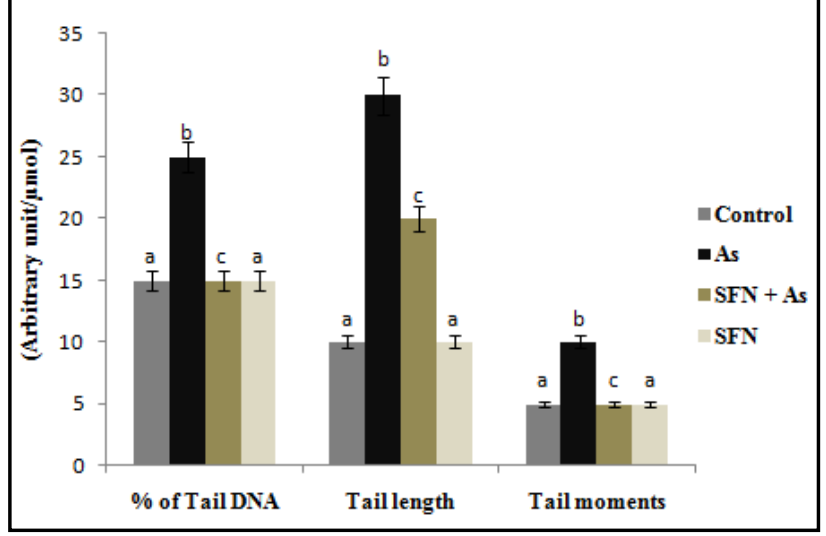

As-exposure resulted in extensive degeneration of hepatocytes with necrosis (NEC), inflammation (INF), vacuolization (VC), inflammatory cell infiltration (ICI) and sinusoidal dilation (SD) (Fig. 8B and C) when compared to control rats. Pre-oral SFN administration to As-treated rats (Fig. 8D) showed near normal hepatocytes without any pathological cypher when compared to control (Fig. 8A) and SFN treated a rat. SFN alone treated rats did not show any histological changes as compared to control.
Fig. 6. Effect of SFN on the impact of As induced RT-PCR changes in SOD1 (A) and CAT (B) of control and experimental rats. Values are expressed as mean \pm SD for groups of eight rats in each. Statistical significance was determined by one way ANOVA (Duncan's Multiple Range Test). Values not sharing a common or same alphabet letter $\left({ }^{\mathrm{a}-\mathrm{f}}\right)$ and they differ significantly

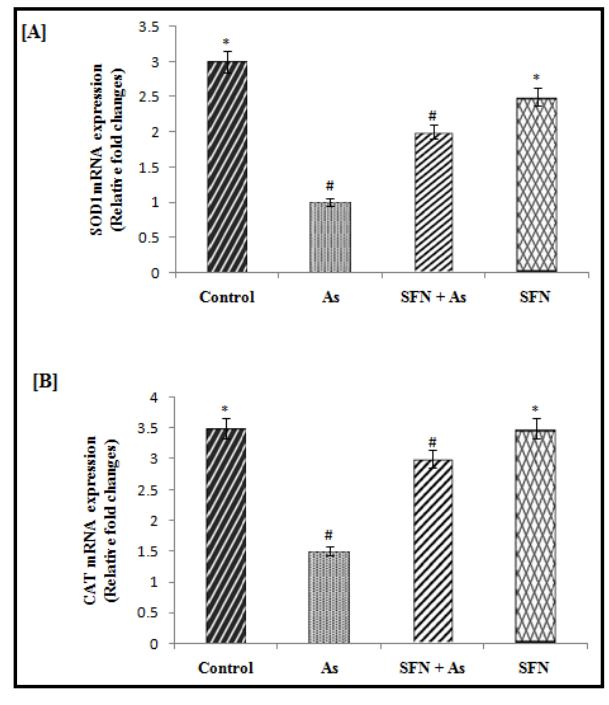
at $\mathrm{P}<0.05$ (Duncan's multiple range test). 


\section{Cellular Physiology Cell Physiol Biochem 2019;52:1203-1222 \begin{tabular}{l|l} 
and Biochemistry Poll 10.33594/000000082 & $\begin{array}{l}\text { O } 2019 \text { The Author(s). Published by } \\
\text { Cell Physiol Biochem Press GmbH\&Co. KG }\end{array}$ \\
\cline { 2 - 3 }
\end{tabular}

Fig. 7. Effect of SFN on the activation of Nrf2 gene via PI3K/Akt signalling pathway in control and As treated rats. Lane 1. Control (Normal DNA), Lane 2. As Control ( $5 \mathrm{mg} / \mathrm{kg}$ BW) (increased DNA damage), Lane 3. SFN + As $(80 \mathrm{mg} / \mathrm{kg} \mathrm{BW})+\operatorname{Ar}(5 \mathrm{mg} / \mathrm{kg} B W)$ (mild DNA damage). Lane 4. Control + SFN (80 mg/kg BW) (Normal DNA). Values not sharing a common or same alphabet letter $\left({ }^{a-f}\right)$ and they differ significantly at $\mathrm{P}<0.05$ (Duncan's multiple range test).

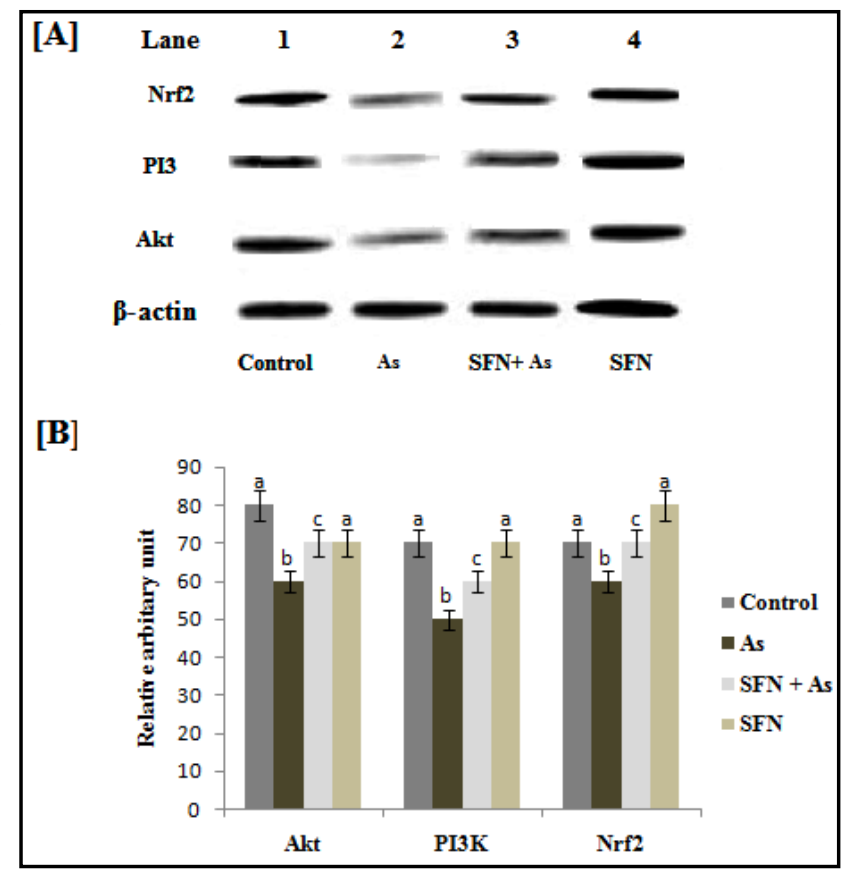

Fig. 8. Effect of SFN on the As induced changes in the histology of liver in the control and experimental animals (A-E). (A) Control rats: Normal liver tissue histology is seen (40x). (B\&C) As treated rats showed degenerative changes, such as degeneration of hepatocytes with necrosis (NEC), inflammation (INF), vacuolization (VC), inflammatory cell infiltration (ICI) and sinusoidal dilation (SD) (40x). (D) As treated rats with SFN: Effective preventing of degenerative changes and shrunken in cytoplasm and nuclei are prominent in liver cells (40x). (E) SFN alone treated rats: Although similar liver tissue histology was observed compared to control (40x). (H\&E 40x).

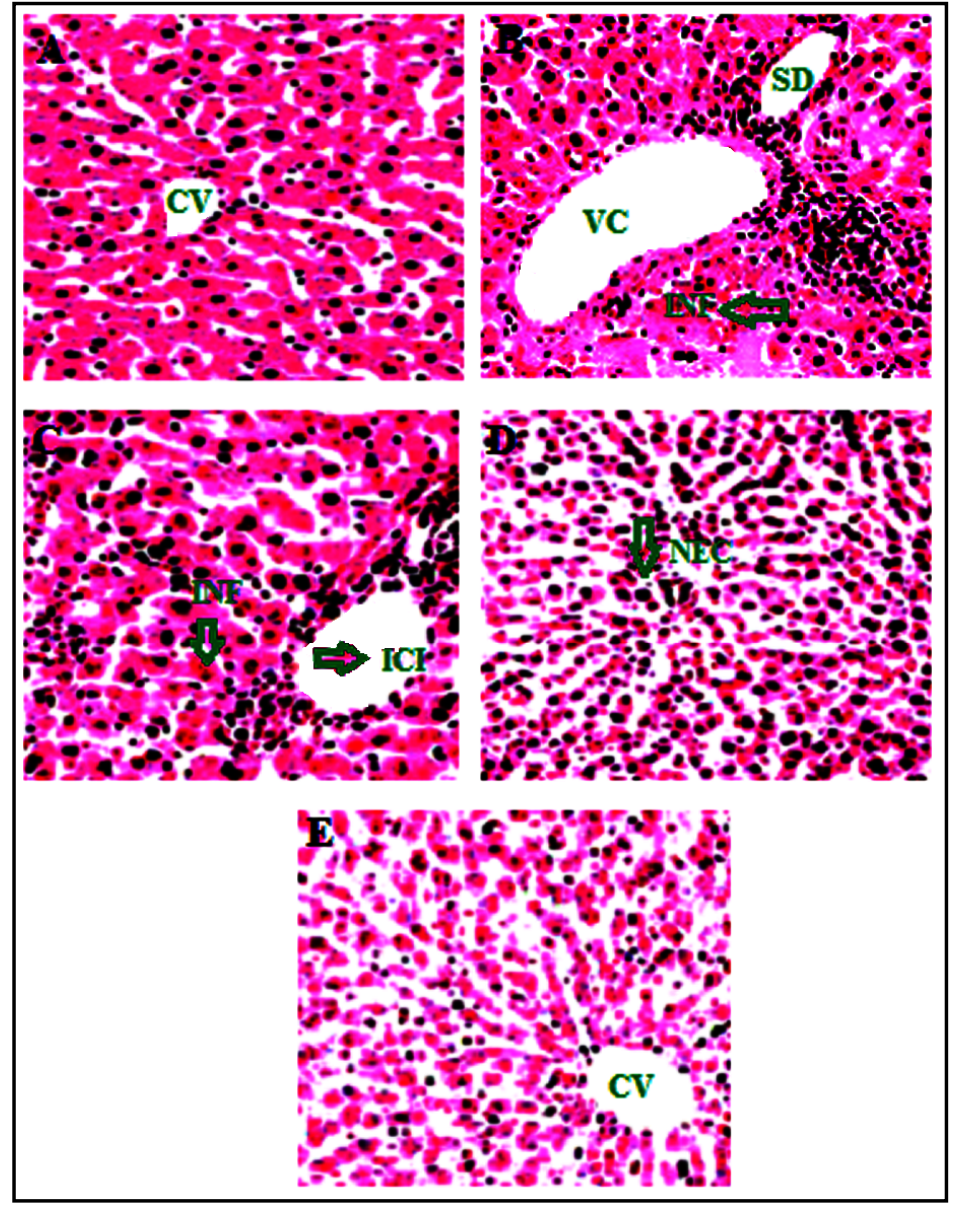




\section{Discussion}

In recent years, there has been a growing concern over the nutritional and medicinal value of sulforaphane (SFN). The antioxidative and hepatoprotective effects of sulforaphane against arsenic intoxication have already been proved [36]. However, a scarcity of literature is observed for the activation of Nrf2 by SFN through the PI3K/Akt pathway in Asinduced liver injury. Nowadays the positive effects of sulforaphane (SFN), widely distributed in cruciferous vegetables (broccoli sprout) have gained more attention. The results indicated that the anti-oxidative property of SFN contributes to the protection against As-induced hepatotoxicity, and the protective effects are related to the activation of the Nrf2/SOD1PI3K/Akt signaling pathway.

The liver is the major target organ for arsenic toxicity and carcinogenesis. Arsenic toxicity involves oxidative damage that plays an imperative role in biochemical alterations [37]. Loss of hepatospecific enzymes in blood serum has been considered as an indicator of hepatic dysfunction and damage. Mostly, serum AST, ALT, ALP, LDH and GGT are the susceptible markers in the diagnosis of hepatic injury [38]. In the present study, we observed, a significant increase in AST, ALT, ALP, LDH and GGT among As- intoxicated rats probably resulting from hepatocytes membrane damage. This result is in accordance with the previous studies using arsenic and other toxicity in the liver [37, 39]. This may be due to As-induced free radical damage in the lipid membrane of hepatocytes seep out these enzymes in the cytosol released into the bloodstream which indicate the liver damage [40]. However, preadministration of SFN remarkably improved these altered hepatic markers by arsenic via its membrane-stabilization properties against ROS-mediated oxidative hepatic injury [41]. Our study suggests that SFN is diminishes cellular oxidative stress/ROS levels and protects the liver injure.

$\delta$-Aminolevulinic acid dehydratase (ALAD) is a sulfhydryl-containing enzyme that catalyzes two molecules of aminolevulinic acid (ALA-substrate) to porphobilinogen during heme synthesis pathway. The reticence of ALAD leads to anaemia and inhibits heme synthesis and shorten the lifespan of circulating red blood cells stimulating the excessive production of the hormone erythropoietin, leading to poor maturation of red cells from their progenitors. In the present study, administration of arsenic exerted a significant depletion in the levels of blood and liver ALAD. This may be due to the high affinity of As with sulfhydryl enzymes, might possible to inhibit the activity (ALAD) direct to significant decrease in levels of aminolevulinic acid (ALA) in respective tissues. Therefore, there was a possibility of increased ALA might generate more reactive oxygen intermediates (ROIs) in the blood and liver tissue. This result of the present study was already in line with the previous report of Bhadauria and Flora, [42]. Restoration of ALAD activity was observed in SFN pre-treated rats compared with As group, due to the direct scavenging of reactive oxygen species (ROS) by SFN and its ability to inhibit the thiol group oxidation in both blood and liver tissues.

Inorganic pentavalent arsenate (iAsV) and trivalent arsenite (iAsIII) are water-soluble compounds and are easily absorbed from the gastrointestinal tract, via biotransformation and eliminated by urinary and faecal excretion as the monomethyl arsenic acid (MMAV) and dimethyl arsenic acid (DMAV) and remains were accumulated in various internal organs, such as liver, kidney, heart, and spleen [43-45]. In the present study, a significant accumulation of As was observed in the liver tissue when compared with control rats, which corroborated with the previous report of Chen et al [46].. This could be due to the metabolism of arsenic 
that is involved in the reduction of arsenic pentoxide into arsenic trioxide that increases the toxicity and bioavailability in the liver as the monomethyl arsenic acid (MMAV) and dimethyl arsenic acid (DMAV). However, pre-administration of SFN to As intoxicated rats showed a significant reduction in the levels of As accumulation as compared with the control group. This could be due to the conjugation of SFN with glutathione, is closely related to its antioxidative potential ameliorates the As accumulation in the liver tissue.

Arsenic act as a pro-oxidant in biological systems and cause lipid peroxidation, which is a basic cellular deteriorating process in the liver [47]. Profound free-radical generation and enhanced lipid peroxidation are the dual face of oxidative stress that initiates the pathogenesis of arsenic-induced hepatotoxicity [48]. In addition to lipid peroxidation, protein carbonylation served as a validated marker for protein oxidation, particularly of the proteins containing amino acid residues like lysine, arginine, proline, and threonine. In the present investigation, there was a significant increase of TBARS, $\mathrm{LOOH}$, and PCC in the liver of arsenic-exposed rats, which confirms the onset of hepatic oxidative stress with an earlier report of Muthumani and Miltonprabu [37]. However, administration of SFN, prior to following As treatment, ameliorated the oxidative stress markers and led to the significant recuperation of all the above-mentioned parameters. Thus, pre-treatment with SFN protests As-induced hepatotoxicity could have been the presence of $\mathrm{N}=\mathrm{C}=\mathrm{S}$ groups in its structure and scavenging As generated free radicals before they reached to the cellular targets.

Indeed, in many systems the cell death was occurring due to reactive oxygen species (ROS) surplus production and the suppression of detoxifying enzymes [49]. To confirm the protective effect of SFN we conducted the experiments by measuring the levels of enzymatic antioxidants in control and experimental groups. Antioxidant enzymes, such as SOD, CAT, GPX, GST, and GR are considered to be the successive contour of cellular defense against oxidative stress-mediated injury in different organs [37]. Assessment of these antioxidant enzymes is an appropriate indirect way to assess the As-induced liver toxicity. SOD is an enzyme responsible for the conversion of superoxide radicals into less harmful products like hydrogen peroxide, while CAT brings about the reduction of hydrogen peroxide and protects tissues from the highly reactive hydroxyl radicals [50]. In the present study, As- intoxication significantly reduced the activity of hepatic SOD and CAT which is in line with the finding of Varghese et al., [51] and Muthumani and Miltonprabu [37]. Glutathione-related enzymes such as GPx, GST and GR function either directly or indirectly as antioxidants to scavenge the free radicals in the body. $\mathrm{GP}_{\mathrm{x}}$ is a selenium-containing enzyme that uses glutathione in decomposing hydrogen peroxides to nontoxic products. In the present study, Arsenic administration lowered the activities of $\mathrm{GP}_{\mathrm{X}}$, GST and GR in the liver.

Nutt et al., [52] reported that the decreased levels of these enzymatic antioxidants in As-treated rats were mainly due to direct inhibition of complex-I mitochondrial electron transport chain, which results in mitochondrial permeability transition, coupled with the generation of ROS and thiol oxidation, which is in accordance with the results of this study. Interestingly, SFN significantly recouped these antioxidant defense systems by bringing them to normal levels. This restoration was mainly due to the strong antioxidant property of SFN and the presence of Isothiocyanates electrophiles at the central carbon atom of the $-\mathrm{N}=$ $\mathrm{C}=\mathrm{S}$ group, which reacts readily with sulfur, nitrogen, and oxygen-based nucleophiles and can directly participate in the activation of Nrf2 Phase II antioxidant under physiological conditions [53].

The reactive oxygen species (ROS) can react with fatty acids and produce highly toxic lipid peroxides and damage the antioxidant skeletal systems that lead to cell death. In this study, we demonstrated that the administration of Arsenic significantly decreased the nonenzymatic antioxidant levels, such as GSH, TSH, Vit. C and Vit. E in liver tissues which are in line with the previous report of Manimaran et al [53].. Similarly, Muthumani and Miltonprabu [38] also reported the impact of As on the decreased levels of non-enzymatic antioxidant in hepatic tissue are well corroborated with our present results. This may be due to the high levels of As-induced ROS generation and formation of arsenic-glutathione conjugates and causes severe depletion of glutathione and its subsequent cellular redox in the liver [54]. 
Pre-administration of SFN has shown the defensive mechanism via preventing the depletion of total glutathione and GSH which lead to increase the ratio of GSH/GSSG and other nonenzymatic antioxidant levels. This may be due to the ability of SFN by protecting the SH groups from the oxidative damage and inhibiting the membrane peroxidation and exhibition of membrane stabilizing properties [55].

Apoptosis is closely associated with ROS homeostasis that is essential for various biological processes in normal cells. The Bcl-2 (B-cell lymphoma-2) family proteins are key regulators of physiological and pathological function. The family consists of cell death promoters Bax, Bad and cell death inhibitors Bcl-2, Bcl-XL, and others. It has been demonstrated that the high ratio of $\mathrm{Bax} / \mathrm{Bcl}-2$ is associated with greater vulnerability to apoptotic activation [56]. In the present study, upon administration of Arsenic increased the pro-apoptotic marker Bax (Bcl2-associated X protein) through down-regulation of anti-apoptotic marker Bcl2 in liver tissue which is in agreement with the earlier report of Thangapandiyan and Miltonprabu [57]. This could be due to the amplified echelon of ROS through As-induced persistent stress in the hepatic portal vein causing irreparable hepatic injury. SFN pretreatment significantly increased the level of Bcl-2 and decreased the Bax levels in As treated rats as described earlier by Chi et al., [58]. This result suggests that SFN exhibits antiapoptotic goodness through the modulation in the Bcl-2 family proteins.

DNA damage is an alteration in the chemical structure of nucleic acid, such as a break in a strand of DNA or a chemically changed base as 8-OHdG that occurs naturally resulting from metabolic or hydrolytic processes. Metabolism releases certain compounds such as reactive oxygen species; reactive nitrogen species, reactive carbonyl species, lipid peroxidation products and alkylating agents will damages and cleaves the chemical bonds in DNA [59]. In the present study As inhibits nucleotide excisin repair involved in the removal of a broad spectrum of DNA lesions induced as the repair of oxidative DNA damage. Moreover, Asinduced ROS disrupts the function of zinc proteins such as XPA and PARP1 thus decreasing the DNA repair capacity and suppresses the expression of key genes in DNA repair via ubiquitin-mediated proteolysis pathways. Additionally, the accumulation of ROS induces cell death by damaging cell membranes through lipid peroxidation. This involves radicals, including ROS and reactive nitrogen species (RNS), interacting with polyunsaturated fatty acid and phospholipids causing DNA damage [60]. Pre-administration of SFN protected the DNA oxidative damage and DNA fragmentation induced by As which was appended to the previous report of Chi et al [58].. One possible mechanism is that SFN would allow the interception of free radicals generated by As before they reach DNA and presume contribution to DNA repair.

In our study, RT-PCR results showed the activation of SOD1 and CAT in As intoxicated rat prior administrated with SFN when compared to control. Leslie et al [61]. reported that As or iAs (III) readily undergoes GSH conjugation to yield As (SG), which is pumped out to the extracellular space and adduct/suppressed the GSH production. Thus, we postulated the increased SOD and CAT isoforms proteins, during pretreatment with SFN that activate the Nrf2 would facilitate decreased As - accumulation in hepatocytes. The current result shows that the treatments with SFN significantly increases Nrf2 protein and ARE promoter activity, and enhances the mRNA protein of Nrf2 target genes, such as SOD1 and CAT activities in Asexposed animals. This result is well accordance with the previous report of Chen et al, [36]. This may be due to SFN induced Nrf2 antioxidant which can be encouraged a wide spectrum of the phase II gene may account for the protection against As induced liver toxicity.

Theanti-apoptoticPI3K/Aktpathwayisessential forcell survival.Thephosphatidylinositol 3-kinase (PI3K) pathway has been well documented as an important signalling transduction pathway that regulates cell growth, proliferation, survival and migration [62]. The v-akt murine thymoma viral oncogene homolog 1 (AKT) is a critical mediator of cell survival [63] and AKT is activated by phosphatidylinositol-4, 5-bisphosphate 3-kinase (PI3-K) in response to growth factors, $\mathrm{Ca}^{2+}$ influx, and extracellular stressors such as oxidative stress [64]. A wide variety of phytochemical from natural products, such as epigallocatechin gallate, naringenin and DATS has been well documented against oxidative cell damage via PI3K/Akt/Nrf2 


\section{Cellular Physiology Cell Physiol Biochem 2019;52:1203-1222 \\ \begin{tabular}{ll|l} 
and Bol: 10.33594/000000082 & $\begin{array}{l}\text { O } 2019 \text { The Author(s). Published by } \\
\text { Cell Physiol Biochem Press GmbH\&Co. KG }\end{array}$ \\
\cline { 2 - 3 }
\end{tabular} \\ Thangapandiyan et al.: Sulforaphane Protects Arsenic Induced Hepatotoxicity}

dependent pathway [65]. The molecular mechanistic pathway of PI3K/Akt is beginning with the extra cellular oxidative stress that activates tyrosine kinase present on the cell surface. Once, biding profitably made the PI3K is activated and stimulate the anti-apoptotic kinase which leads to Nrf2 phosphorylation from its suppressor gene Keap1, thereby facilitating the translocation of Nrf2 to the nucleus and thereby stimulating phase II antioxidant enzymes [66].

Recently, SFN was found to induce Nrf2 mediated antioxidant dependent pathway in liver cells which was reported by Richard et al [67].. However, SFN activates Nrf2 and other subsequent antioxidant in the liver via PI3K/Akt signal is still unknown. In order to prove, we observed that decreased PI3K/Akt levels in As- intoxicated rat with decreased Nrf2 levels as compared to control, which may be due to augmented ROS level cause hepatic damage. Pre-administration of SFN significantly arrest the formation of free radicals and oxidative stress in As-intoxicated animals which are in line with the earlier report of Xian et al., [68]. Because, SFN has already been well documented for its antioxidant and antiapoptotic property in various organs [69]. However, the precise molecular mechanism for activation of Nrf2 by SFN is still unclear. We demonstrated the first time for the activation of Nrf2 gene via PI3K/Akt mediated signaling pathway in liver tissue. The most abundant glucosinolate in broccoli is glucoraphanin, which upon hydrolysis by myrosinase or intestinal flora yields the isothiocyanates and sulforaphane (R-1-isothiocyanato-4-methylsulfinyl butane, SF). After absorption, sulforaphane (SFN) undergoes conjugation to glutathione, a reaction catalyzed by Glutathione-S-Transferases (GST). Subsequently, step-wise cleavage of glutamine and glycine by the enzymes $\gamma$-glutamyl transpeptidase (GTP) and cysteinylglycinase (CGase) respectively yields L-cysteine conjugate. This latter acetylated by the enzyme $\mathrm{N}$-acetyltransferase (NAT) to produce $\mathrm{N}$-acetyl-L-cysteine thus activates the PI3K/Akt signaling pathway might activate the nuclear factor 2 (erythroid-2 related-Nrf2) in defending against a number of oxidative cellular redox homeostasis and limiting oxidative hepatic damage [70].

Histopathological study showed many abnormalities in the liver of As-treated rats, including necrosis (NEC), inflammation (INF), vacuolization (VC), inflammatory cell infiltration (ICI) sinusoidal dilation (SD) and distinct damage of cytoplasmic organelles. This obtained histopathological abnormalities demonstrated that the As compounds generate reactive oxygen species during their metabolism, in cells and causes tissue damage [37]. In the present study, the findings of liver injury were markedly attenuated in the SFN pretreated group. The results of this study further supported by the up-regulation of endogenous antioxidant through the activation of Nrf2 can prevent the hepatic damage and maintain the normal histoarchitecture.

\section{Conclusion}

In summary, the results of the present study demonstrated that SFN afford therapeutic and prophylactic efficacy against As induced oxidative hepatic damage through its strong antioxidant property. SFN ameliorated the As induced alternation in liver through the activation of Nrf2 by PI3K/Akt mediated pathway. Moreover, Nrf2 has emerged as a target factor for wide battery of genes that aid in the detoxification and elimination of As induced liver oxidative damage (Fig. 9). Further in-depth studies may establish this bioactive sulforaphane, as a possible candidate for the treatment of arsenic-induced oxidative stress associated liver complications in near future. 
Fig. 9. Graphical abstract shows the protective molecular mechanism of SFN against Asinduced oxidative stress in the liver via PI3K/Akt mediated Nrf2 signaling pathway.

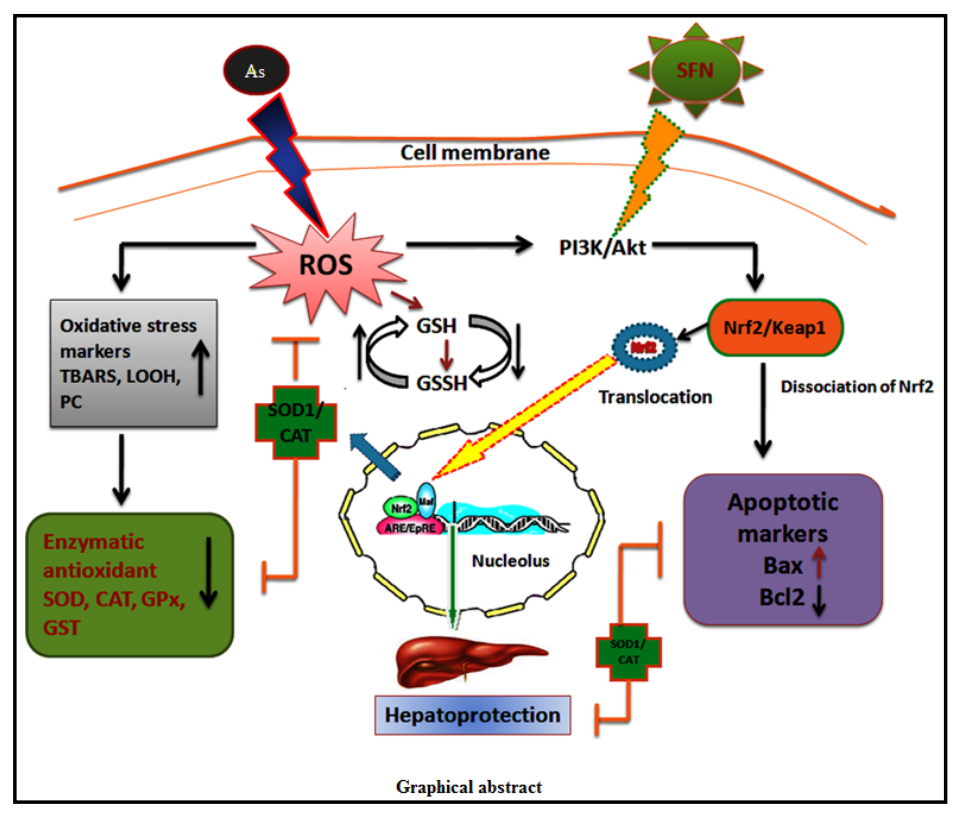

\section{Acknowledgements}

The authors would like thank to the Professor and Head of the Department of Zoology, Bharathiar University for providing laboratory facilities and Dr.STP acknowledge DST-SERB for proving National Postdoctoral Fellowship (N-PDF/2016/003063), New Delhi, India.

\section{Disclosure Statement}

The authors declared no conflicts of interest.

\section{References}

1 Argos M, Kalra T, Rathouz PJ, Chen Y, Pierce B, Parvez F, Islam T, Ahmed A, Rakibuz-Zaman M, Hasan R, Sarwar G, Slavkovich V, Van Geen A, Graziano J, Ahsan H: Arsenic exposure from drinking water, and all-cause and chronic disease mortalities in Bangladesh (HEALS): a prospective cohort study. Lancet 2010;376:252-258.

- 2 Chen Y, Graziano JH, Parvez F, Liu M, Slavkovich V, Kalra T, Argos M, Islam T, Ahmed A, Rakibuz-Zaman M, Hasan R, Sarwar G, Levy D, Van Geen A, Ahsan H: Arsenic exposure from drinking water and mortality from cardiovascular disease in Bangladesh: a prospective cohort study. BMJ 2011;342:d2431.

3 WHO: Arsenic in drinking water. Fact Sheet No. 210, 1999. Geneva, World Health Organisation.

- 4 Vieira C, Morais S, Ramos S, Delerue-Matos C, Oliveira MB: Mercury, cadmium, lead and arsenic levels in three pelagic fish species from the Atlantic Ocean: intra- and inter-specific variability and human health risks for consumption. Food Chem Toxicol 2011;49:923-932.

5 Ratnaike RN: Acute and chronic arsenic toxicity. Postgrad Med J 2003;79:391-396.

- 6 Ercal N, Gurer-Orhan H, Aykin-Burns N: Toxic Metals and Oxidative Stress Part I: Mechanisms Involved in Metal-induced Oxidative Damage. Curr Top Med Chem 2001;1:529-539.

7 Patra PH, Bandyopadhyay S, Kumar R, Datta BK, Maji C, Biswas S, Dash JR, Sar TK, Sarkar S, Manna SK, Chakraborty AK, Mandal TK: Quantitative imaging of arsenic and its species in goat following long term oral exposure. Food Chem Toxicol 2012;50:1946-1950.

8 Pan X, Dai Y, Li X, Niu N, Li W, Liu F: Inhibition of arsenic induced-rat liver injury by grape seed exact through suppression of NADPH oxidase andTGF/Smad activation.Toxicol Appl Pharmacol 2011;254:323331. 


\section{Cellular Physiology Cell Physiol Biochem 2019;52:1203-1222 \begin{tabular}{l|l|l}
\cline { 2 - 3 } DOI: $10.33594 / 000000082$ & & 2019 The Author(s). Published by
\end{tabular} and BIOChemistry Published online: 19 April $2019 \quad$ Cell Physiol Biochem Press GmbH\&Co. KG \\ Thangapandiyan et al.: Sulforaphane Protects Arsenic Induced Hepatotoxicity}

9 Muthumani M, Miltonprabu S: Silibin in potentially protects arsenic-induced oxidative hepatic dysfunction in rats. Toxicol Mech Methods 2012;22:277-288.

- 10 Lin A, Zhang X, Zhu YG, Zhao FJ: Arsenate-induced toxicity: effects on antioxidative enzymes and DNA damage in Vicia faba. Environ Toxicol Chem 2008;27:413-419.

- 11 Shi H, Djikeng A, Tschudi C, Ullu E: Argonaut protein in the early divergent eukaryote Trypanosoma brucei: control of small interfering RNA accumulation and retroposon transcript abundance. Mol Cell Biol 2004;24:420-427.

- 12 Flora SJS, Bhadauria S, Kannan GM, Singh N: Arsenic-induced oxidative stress and the role of antioxidant supplementation during chelation: a review. J Environ Biol 2007;28:333-347.

13 Miltonprabu S, Muthumani M: Dimethoxycurcumin potentially protects arsenic-induced oxidative hepatic injury, inflammation and apoptosis via Nrf2-Keap1 signaling in rats. Biomed Prevent Nutr 2014;4:561-577.

14 Veeranki OL, Bhattacharya A, Marshall JR, Zhang Y: Organ-specific exposure and response to sulforaphane, a key chemopreventive ingredient in broccoli: implications for cancer prevention. Br J Nutr 2013;109:2532.

15 Kensler T, Egner P, Agyeman Visvanathan P, Groopman J, Chen T. Chen Y, Fahey J, Talalay P: Keap1-Nrf2 Signaling: A Target for Cancer Prevention by Sulforaphane, in Pezzuto JM, Suh N (eds.): Natural Products in Cancer Prevention and Therapy. Springer, Berlin, Heidelberg, 2013, pp-163-177.

- 16 Yeh CT, Yen GC: Effect of sulforaphane on metallothionein expression and induction of apoptosis in human hepatoma HepG2 cells. Carcinogenesis 2005;26:2138-2148.

17 Jung Noh, JR, Yong-Hoon Kim, YJ, Hwang JH, Choi DH, Kyoung-ShimKim KS, Oh, WK, Le CH: Sulforaphane protects against acetaminophen-induced hepatotoxicity. Food Chem Toxicol 2015;80:193-200.

18 Chi X, Zhang R, Shen N, Jin Y, Alina A, Yang S, Lin S: Sulforaphane reduces apoptosis and oncosis along with protecting liver injury induced ischemic reperfusion by activating the Nrf2/ARE pathway. Hepatol Int 2015;9:321-329.

19 Gaona GL, Molina-Jijón E, Tapia E, Zazueta C. Hernández-Pando R, Calderón-Oliver M, Zarco-Márquez G, Pinzón, E: Protective effect of sulforaphane pretreatment against cisplatin-induced liver and mitochondrial oxidant damage in rats. Toxicol 2011;286:20-27.

20 El-demerdash M, Yousef MI, Radwan ME: ameliorating the effect of curcumin on sodium arsenite-induced oxidative damage and lipid peroxidation in different rat organs. Food Chem Toxicol 2009;47:249-254.

21 Rosalki SB, Rav D, Lachman D, Prentice M: Determination of serum gamma-glutamyl transpeptidase activity and its clinical applications. Ann Clin Biochem 1970;7:143-147.

22 Berlin A, Schaller KH: European standardized method for the determination of delta-aminolevulinic acid dehydratase activity in blood. Z Klin Chem Klin Biochem 1974;12:389-390.

- 23 Niehaus WG, Samuelsson BJ: Formation of malonaldehyde from phospholipid arachidonate during microsomal lipid peroxidation. Eur J Biochem 1968;6:126-130.

24 Jiang ZY, Hunt JY, Wolff SP: Detection of lipid hydroperoxides using the "fox method. Anal Biochem 1992;202:384-389.

25 Levine RL, Garland D, Oliver CN, AmicA, Climent I, Lenz AG, Ahn BW, Shaltiel S, Stadtman ER: Determination of carbonyl content in oxidatively modified proteins. Method Enzymol 1999;186:464-478.

26 Kakkar P, Das B, Viswanathan PN: A modified spectrophotometric assay of superoxide dismutase. Indian J Biochem Biophys 1984;21:130-132.

27 Sinha AK: Colourimetric assay of catalase. Anal Biochem 1972;47:389-394.

28 Rotruck JT, Pope AL, Ganther H, Swanson A, Bhafeman DG, HoekstraWG: Selenium: biochemical role as a component of glutathione peroxidase. Science 1973;179:588-590.

29 Habig WH, Pabst MJ, Jakoby WB: Glutathione S-transferases. The first enzymatic step in mercapturic acid formation. J Biol Chem 1974;249:7130-7139.

30 Horn HD, Burns FH: Assay of glutathione reductase activity. In Bergmeyer HV (ed.): Methods of Enzymatic Analysis. New York, Academic Press, 1978, pp 142-146.

- 31 Moron MS, Deflere JW, Mannervick B: Levels of glutathione, glutathione reductase and glutathione-Stransferase activities in rat hung and liver. Biochem Biophys Acta 1979;585:67-78.

- 32 Ellman GL: Tissue sulfhydryl groups. Arch Biochem Biophys 1959;82:70-77.

- 33 Omaye ST, Turnbull TD, Sauberlich HC: Selected method for the determination of ascorbic acid in animal cells, tissues and fluids. In McCormick DB, Wright DL (eds.): Methods in Enzymology. New York, NY, Academic Press, 1979, pp 3-11. 


\section{Cellular Physiology Cell Physiol Biochem 2019;52:1203-1222 \begin{tabular}{l|l|l} 
DOI: $10.33594 / 000000082$ & $(c) 2019$ The Author(s). Published by
\end{tabular} and BIOChemistry Published online: 19 April $2019 \quad$ Cell Physiol Biochem Press GmbH\&Co. KG \\ Thangapandiyan et al.: Sulforaphane Protects Arsenic Induced Hepatotoxicity}

- 34 Desai ID: Vitamin E analysis methods for animal tissues. Meth Enzymol 1984;105:138-147.

- 35 Singh NP, McCoy MT, Tice RR, Schneider EL: A simple technique for quantitation of low levels of DNA damage in individual cells. Exp Cell Res 1988;175:184-191.

- 36 Chen X, Liu J, Chen SY: Sulforaphane protects against ethanol-induced oxidative stress and apoptosis in neural crest cells by the induction of Nrf2-mediated antioxidant response. Br J Pharmacol 2013;169:437448.

- 37 Muthumani M, Miltonprabu S: Ameliorative efficacy of tetrahydrocurcumin against arsenic-induced oxidative damage, dyslipidemia and hepatic mitochondrial toxicity in rats. Chemical-Biological Interactions 2015;235:95-105.

38 Muthumani M, Miltonprabu S: Silibinin attenuates arsenic-induced alterations in serum and hepatic lipid profiles in rats. J Appl Pharm Sci 2013;3:132-138.

39 Thangapandiyan S, Miltonprabu S: Epigallocatechin gallate effectively ameliorates fluoride-induced oxidative stress and DNA damage in the liver of rats. Can Journ Physiol Pharmacol 2013;91:528-537.

40 Majumdar S, Karmakar S, Maiti A, Choudhury M, Ghosh A, Das AS, Mitra C: Arsenic-induced hepatic mitochondrial toxicity in rats and its amelioration by dietary phosphate. Environ Toxicol Pharmacol 2011;31:107-118.

- 41 Shinkai Y, Sumia D, Fukami I, Ishiia T, Kumagaia Y: Sulforaphane, an activator of Nrf2, suppresses cellular accumulation of arsenic and its cytotoxicity in primary mouse hepatocytes. FEBS Letters 2006;580:17711774.

42 Bhadauria S, Flora SJ: Arsenic induced inhibition of delta-aminolevulinate dehydratase activity in rat blood and its response to meso 2,3-dimercaptosuccinic acid and monoisoamyl DMSA. Biomed Environ Sci 2004:17:101-108.

43 Cui X, Kobayashi Y, Hayakawa T, Hirano S: Arsenic speciation in bile and urine following oral and intravenous exposure to inorganic and organic arsenic in rats. Toxicol Sci 2004;82:478-487.

44 Vahter M: Mechanisms of arsenic biotransformation. Toxicol 2002;181-182:211-217.

45 Chung JS, Kalman DA, Moore LE, Kosnett MJ, Arroyo AP, Beeris M, Mazumder DN, Hernandez AL, Smith AH: Family correlations of arsenic methylation patterns in children and parents exposed to high concentrations of arsenic in drinking water. Environ Health Perspect 2002;110:729-733.

46 Chen CJ, Chen CW, Wu MM, Kuo TL: Cancer potential in liver, lung, bladder and kidney due to ingested inorganic arsenic in drinking water. Br J Cancer 1992;66:888-892.

47 Flora SJ: Arsenic-induced oxidative stress and its reversibility following combined administration of $\mathrm{N}$-acetylcysteine and meso 2, 3-dimercaptosuccinic acid in rats. Clin Exp Pharmacol Physiol 1999;26:865869.

48 Bashir S, Sharma Y, Irshad M, Gupta SD, Dogra TD: Arsenic-induced cell death in liver and brain of experimental rats. Basic Clin Pharmacol Toxicol 2006;98:38-43.

- 49 Proskuryakov SY, Konoplyannikov AG, Gabai VL: Necrosis: a specific form of programmed cell death? Exp Cell Res 2003;283:1-16.

50 Brioukhanov AL, Netrusov AL: Catalase and superoxide dismutase; distribution, properties, and physiological role in cells of strict anaerobes. Biochemistry 2004;69:949-962.

51 Mathews VV, Paul MS, Abhilash M, Manju A, Abhilash S, Nair RH: Mitigation of hepatotoxic effects of arsenic trioxide through omega-3 fatty acid in rats. Toxicol Ind Health 2014;30:806-813.

52 Nutt LK, Gogvadze V, Uthaisang W, MirnikjooB, McConkey DJ, Orrenius S: Indirect effects of Bax and Bak initiate the mitochondrial alterations that lead to cytochrome c release during arsenic trioxide-induced apoptosis. Cancer Biol Ther 2005;4:459-467.

53 Manimaran A, Sarkar SP, Sankar S: Influence of repeated pre-exposure to arsenic on acetaminopheninduced oxidative stress in liver of male rats. Food Chem Toxicol 2010;48:605-610.

54 Han D, Hanawa N, Saberi B, Kaplowitz N: Mechanisms of liver injury. III. Role of glutathione redox status in liver injury. Am. J. Physiol, Gastrointest. Liver Physiol 2006;290:G1-G7.

- 55 Zhao HD, Zhang F, Shen G, Li YB, Li YH, Jing HR, Feima L, Yao J, Tian X: Sulforaphane protects liver injury induced by intestinal ischemia-reperfusion through Nrf2-ARE pathway. World J Gastroenterol 2010;16:3002-3010.

- 56 Lee JH, Jung JY, Jeong JY, Park JH, Yang KH, Choi NK: Involvement of both mitochondrial- and death receptor-dependent apoptotic pathways regulated by Bcl-2 family in sodium fluoride-induced apoptosis of the human gingival fibroblasts. Toxicol 2008;243:340-347. 


\section{Cellular Physiology Cell Physiol Biochem 2019;52:1203-1222 \begin{tabular}{ll|l|l} 
DOI: 10.33594/000000082 & (O) 2019 The Author(s). Published by \\
and Biochemistry
\end{tabular} and Biochemistry Published online: 19 April 2019 Cell Physiol Biochem Press GmbH\&Co. KG \\ Thangapandiyan et al.: Sulforaphane Protects Arsenic Induced Hepatotoxicity}

- 57 Thangapandiyan S, Miltonprabu S: Epigallocatechin gallate supplementation protects against renal injury induced by fluoride intoxication in rats: Role of Nrf2/HO-1 signaling. Toxicol Rep 2014;1:12-30.

- 58 Chi X, Zhang R, Shen N, Jin Y, Alina A, Yang S, Lin S: Sulforaphane reduces apoptosis and oncosis along with protecting liver injury induced ischemic reperfusion by activating the Nrf2/ARE pathway. Hepatol Int 2015;9:321-329.

59 De Bont R, van Larebeke N: Endogenous DNA damage in humans: a review of quantitative data. Mutagenesis 2004;19:169-185.

60 Nair U, Bartsch H, Nair J: Lipid peroxidation-induced DNA damage in cancer-prone inflammatory diseases: a review of published adduct types and levels in humans. Free Radical Biol Med 2007;43:1109-1120.

61 Leslie EM, Haimeur A, Waalkes MP: Arsenic transport by the human multidrug resistance protein 1 (MRP1/ ABCC1). Evidence that a tri-glutathione conjugate is required. J Biol Chem 2004;279:3270032708.

62 El-Mihi KA, Kenawy HI, El-Karef, Elsherbiny NM, Eissa LA: Naringin attenuates thioacetamide-induced liver fibrosis in rats through modulation of the PI3K/Akt pathway. Life Science 2017;15:187:50-57.

63 Yoon SO, Kim MM, Park SJ, Kim D, Chung J, Chung AS: Selenite suppresses hydrogen peroxide-induced cell apoptosis through inhibition of ASK1/JNK and activation of PI3-K/Akt pathways. FASEB J 2002;16:111113.

- 64 Franke TF, Kaplan DR, Cantley LC: PI3K: downstream AKTion blocks apoptosis. Cell 1997;88:435-437.

- 65 Na HK, Surh YJ: Modulation of Nrf2 mediated antioxidant and detoxifying enzyme induction by the green tea polyphenol EGCG. Food Chem Toxicol 2008;46:1271-1278.

66 Nguyen T, Yang CS, Pickett CB: The pathways and molecular mechanisms regulating Nrf2 activation in response to chemical stress. Free Radic Biol Med 2004;37:433-441.

67 Zhou R, Lin J, Wu D: Sulforaphane induces Nrf2 and protects against CYP2E1-dependent binge alcoholinduced liver steatosis. Biochim Biophys Acta 2014;1840:209-218.

$68 \mathrm{Xu} \mathrm{XH,} \mathrm{Li} \mathrm{GL,} \mathrm{Wang} \mathrm{BA,} \mathrm{Qin} \mathrm{Y,} \mathrm{Bai} \mathrm{SR,} \mathrm{Rong} \mathrm{J,} \mathrm{Deng} \mathrm{T,} \mathrm{Li} \mathrm{Q:} \mathrm{Diallyl} \mathrm{trisulfide} \mathrm{protects} \mathrm{against} \mathrm{oxygen} \mathrm{glucose}$ deprivation induced apoptosis by scavenging free radicals via the PI3K/Akt mediated nrf2/Ho-1 signaling pathway in B35 neural cells. Brain Res 2015;1614:38-50.

69 Tope AM, Roger PF: Evaluation of protective effects of sulforaphane on DNA damage caused by exposure to low levels of pesticide mixture using comet assay. J Environ Sci Health B 2009;44:657-662.

70 Lin W, Wu RT, Wu T, Khor TO, Wang H, Kong AN: Sulforaphane suppressed LPS-induced inflammation in mouse peritoneal macrophages through Nrf2 dependent pathway. Biochem Pharmacol 2008;76:967-973. 